\title{
THEORY AND EVIDENCE ON THE RESOLUTION OF FINANCIAL DISTRESS*
}

\author{
David T. Brown \\ Warrington College of Business \\ University of Florida \\ Brian A. Ciochetti \\ Kenan-Flagler School of Business \\ University of North Carolina \\ Timothy J. Riddiough \\ Graduate School of Business \\ University of Wisconsin-Madison
}

February 2005

\footnotetext{
${ }^{*}$ We are grateful for financial support provided by the Real Estate Research Institute.
} 


\title{
THEORY AND EVIDENCE ON THE RESOLUTION OF FINANCIAL DISTRESS*
}

\begin{abstract}
This paper provides theory and evidence on the resolution of financial distress for an owner-managed project. The main insights of the model are: (1) borrower default is endogenous; i.e., the anticipated outcome of default determines whether or not default occurs in the first place, (2) the restructuringforeclosure decision depends crucially on the interaction between project value and industry liquidity and (3) the lender waits for the industry to recapitalize before selling assets obtained through foreclosure. An empirical analysis of a large sample of defaulted commercial real estate loans supports many of the model predictions, including the existence of endogenous borrower default, significant underinvestment in distressed assets, liquidity provision vis-à-vis delayed asset sales in response to weak industry conditions, and firesale discounts that vary depending on market conditions at the time of foreclosure.
\end{abstract}

\section{Introduction.}

This paper considers the causes and especially the consequences of financial distress. The theoretical setting is one of a simply-capitalized owner-managed project. Financial distress occurs when a shock to project value leaves the owner-manager with a reduced equity stake and hence poor incentives to manage the project. In response to the project value shock, the owner-manager has incentives to default on the debt payment. If default occurs the lender must decide whether to restructure the loan or foreclose.

In a restructuring, the lender must scale back the promised debt payments (recreate the manager's equity stake) to give the owner-manager incentives to maximize the value of the project. As an alternative to restructuring, foreclosure can occur. A well-capitalized buyer of a foreclosed asset provides her own equity stake, which allows the lender to capture a share of the project rents. The willingness to pay for the asset depends on the outsider buyer's wealth and management skill. The lender therefore forecloses when there exists a potential buyer that is both well-capitalized and sufficiently skilled at managing the project.

When deciding whether to default or not, the incumbent owner-manager anticipates whether the defaulted loan will be restructured or foreclosed. If a restructuring is anticipated, the owner-

\footnotetext{
* This paper has benefited from comments and suggestions made by Andres Almazan, Mark Flannery, Don Hausch, Tracy Lewis, David Ling, Antonio Mello, Mike Ryngaert, David Sappington, Sheridan Titman and Joe Williams, as well as by seminar participants at the Hong Kong University of Science and Technology, University of California-Berkeley, University of Cincinnati, University of Colorado, University of Connecticut, University of Wisconsin-Madison, the annual meetings of the American Finance Association, the Asia-Pacific Economic Association, the Homer Hoyt Institute for Advanced Studies, and the Vail Real Estate Conference.
} 
manager defaults and obtains debt forgiveness. If foreclosure is anticipated, the owner-manager does not default if the value of the equity stake exceeds the cost of keeping the loan current. However, if the value of the equity stake is sufficiently low, default and foreclosure occur.

Conditional on foreclosure the lender either sells the asset immediately or manages the asset to be sold at a later date. It is costly for the lender to carry the asset in inventory, since it is most effectively managed by industry experts with an equity stake in the project. When the pool of outside buyers is strong, the foreclosed asset is immediately sold since there is little gain from waiting for better-capitalized buyers to emerge. When there are no well-capitalized potential buyers, the lender forecloses and incurs the cost of carrying the asset in anticipation of a higher sales price in the near future.

A unique feature of the model is that project value and potential buyer wealth interact to determine if and when default occurs and the lender's payoffs in default. For example, default and foreclosure occur when project value shock is sufficiently large and the pool of outside buyers is strong. The foreclosed asset is sold quickly with the sale proceeds allocated according to the absolute priority rule. Thus, in this case, the decision to default resembles the optimal exercise of a put option, as in models in the tradition of Black and Scholes (1973) and Merton (1974). ${ }^{1}$

In contrast, when the pool of outside buyers is weak, the borrower defaults since the lender has an incentive to forgive debt. In cases when the continuation value is positive, the borrower defaults "strategically" to obtain debt forgiveness. In other models of strategic default, such as Anderson and Sundaresan (1996), Mella-Barral and Perraudin (1997), and Fan and Sundaresan (2000), transaction costs and taxes create incentives for strategic default. In our model the incentive for strategic default varies with the wealth of potential buyers and occurs because investment incentives are only improved in a restructuring, in which the borrower extracts a large share of the rents.

Like Bulow and Shoven (1978) and Stromberg (2000), we consider whether an asset is liquidated or reorganized conditional on default. In our model liquidation is avoided when: (1) the assets are worth more to the owner-manager in continuation, and (2) market conditions are such that lender gains associated with foreclosure and asset sale are low. In Stromberg (2000) and this model, the value of the assets in continuation depends on the expertise of the manager of the distressed asset (the continuation value is exogenous in Bulow and Shoven (1978)). In Bulow and Shoven (1978) and Stromberg (2000), the bank lender's share of the gains from avoiding liquidation is reduced by wealth transfers to other creditors, and hence distressed assets can be sold to lower valued owners.

\footnotetext{
${ }^{1}$ More recent examples of models in this tradition include Titman, Tompaidis and Tsplakov (2001) and Acharya and Carpenter (2002).
} 
In contrast, in this owner-manager model, there is a single lender and hence there are no wealth transfers among creditors. Because a sizable equity stake is required to restore investment incentives, the gains from a restructuring accrue largely to the owner-manager. Consequently, lender gains to an outside sale must be low (industry conditions in terms of management skill and wealth must be weak) for a restructuring to occur. An interesting feature of our model is that distressed assets can be sold to less efficient managers even when there is a single lender; i.e., foreclosures occur when there are no lender coordination problems.

Payoffs to the lender from foreclosure are positively related to the liquidity of potential buyers, as in Shleifer and Vishny (1992). In their model, the well capitalized buyer makes better investment decisions than the distressed borrower. In our model, the gains from selling to an outsider occur because: 1) the buyer is more efficient at managing the asset than the incumbent borrower, or 2) the buyer's wealth is sufficient to compensate for (slight) management inefficiencies, thus paying the lender a sufficiently large share of the gains from improving the investment incentives. The lender prefers to sell the distressed asset to a well capitalized buyer in these cases, even when there are no impediments to a reorganization that improves the distressed borrower's investment incentives.

Unique predictions of our model emerge from the interaction of project value shock magnitudes, the relative efficiency of management, and the wealth levels of potential buyers as they impact endogenous default decisions and the outcomes conditional on default. Specifically, the model yields two empirical predictions that are subsequently examined with available data. First, the model predicts that the timing of the sale of foreclosed assets depends on current and expected levels of potential buyer wealth. Second, based on part on the endogeneity of borrower default, defaulted loans are more likely to be restructured when the shock to project value is small, the wealth of potential buyers is low and incumbent management is more efficient than outside managers.

Model implications are tested with a data set of over 600 financially distressed commercial real estate assets covering the severe downturn and rebound in commercial real estate values during the late 1980s and early 1990s. The assets were all owner-managed, and the overwhelming majority had a single loan against the property. The data originate from a single large insurance company that was a major player in the market for permanent commercial real estate loans, where analysis indicates that the data are representative of the industry as a whole.

The data indicate whether the distressed loans were reorganized or foreclosed, as well as the time span between foreclosure and the sale of the asset. Consistent with the model structure, restructurings involved debt write-downs rather than exchanges of equity for debt. Proxies for the wealth of potential buyers, as well as cross-sectional differences in project value shock magnitudes and 
management intensity, are utilized for testing the model predictions regarding the restructuringforeclosure decision and the timing of foreclosed asset sale.

The analysis of foreclosed asset sale timing is based on predictions that assets are sold relatively quickly when potential buyers are well-capitalized and delayed in the absence of wellcapitalized buyers. During the worst years of the real estate downturn (when potential buyer wealth was low), only about $12 \%$ of the foreclosed asset inventory were sold per annum. However, during 1993 and 1994, the years when the industry began an extended recovery, the lender sold 32\% and 40\% of its year-beginning inventory. The average time in inventory was longer for assets sold during this latter period, reflecting the delayed sale of assets obtained through foreclosure during the downturn. Estimates of a proportional hazards model reveal cross-sectional patterns that are consistent with these time-series outcomes. For example, office properties, which experienced an especially severe industry shock, were sold at a slower rate than apartment properties, which experienced a much smaller shock.

The pattern of asset sales suggests that: (1) an adverse shock to wealth created a wedge between the fundamental value of assets and the price at which assets could be sold, and (2) the lender perceived that asset values would return to fundamental values as either well-capitalized outsiders entered the industry or insiders recapitalized. Indeed, as originally predicted by Shleifer and Vishny (1992), we find that the magnitude of firesale discounts vary depending on market conditions at the time of liquidation, and additionally that the lender's endogenous sale timing decision smoothes variation in the firesale discount as measured at the time of asset sale. These findings complement existing empirical evidence on the relation between industry liquidity and asset value. For example, Pulvino (1998) and Brown (2000) find a relation between the transacted prices of distressed assets and the financial condition of the seller and buyer, whereas we find that the timing of the asset sale and subsequent discount depend on industry liquidity.

The data on restructuring versus foreclosure outcomes reveal that foreclosure occurred more frequently for loans that defaulted during the worst years of the downturn. These were years when it was also more difficult for the lender to sell foreclosed property. In contrast, restructuring was more prevalent as market conditions improved and there was a ready market for foreclosed properties. These outcomes are consistent with endogenous borrower default; indeed, they are difficult to reconcile without appealing to endogenous default.

Our empirical findings follow from the particular features of the data. The data show that the deep downturn in commercial real estate values simultaneously reduced the wealth of potential buyers and made option-based default attractive to the borrower. Although lenders prefer restructuring when industry wealth is low, foreclosure rates were high since a large number of borrowers were willing to 
walk away from the assets. In contrast, during the recovery period, continuation values were higher and borrowers only defaulted when they anticipated a restructuring.

The choice to restructure versus foreclose is regressed against cross-sectional and time varying proxies for the project value shock, sector wealth, and asset management specificity. The logit model estimations support the idea that restructuring conditional on default is negatively related to the size of the project value shock and the strength of the market for foreclosed assets, and positively related to the asset's management specificity. Furthermore, logit model estimations and the analysis of the timing of the sale of foreclosed assets support the predictions of the model that, when potential buyer wealth is low, the lender prefers restructuring over foreclosure and delayed sale over foreclosure and immediate sale.

Our model predicts that projects that are foreclosed will have experienced, on average, worse pre-default operating performance than projects that are restructured. This occurs because the borrowers that anticipate a restructuring readily default, while borrowers that anticipate foreclosure default only when prospects are very dim. Stromberg (2000) also argues that foreclosed assets experience poor pre-default operating performance. In his setting poor performing assets are badly managed and liquidation transfers the asset to a more efficient operator. Note that our model is capable of addressing this cause and effect relation. However, in the context of our data, idiosyncratic management problems are unlikely to explain our finding that loans collateralized by poorly performing property sectors were more likely to be foreclosed. Rather, general equilibrium factors seem to explain the outcomes - a prediction that nests within our model.

The data contain information about capital expenditures made by the lender to improve or reposition the foreclosed properties prior to asset sale. We find that the lender made capital expenditures on the order of three to four times that of a typical non-distressed owner-manager. This suggests that financially distressed borrowers significantly underinvested in property maintenance or were unwilling to make positive net present value investments to reposition the property in the face of changing market conditions. These results complement evidence presented by Asquith, Gertner and Scharfstein (1994) that firms reduce their capital expenditures following financial distress.

The remainder of this paper is organized as follows. Section 2 provides a model of borrower and lender behavior for a financially distressed owner-managed project. Section 3 presents the data. A descriptive empirical analysis of the decision to foreclose versus reorganize and the decision to sell versus manage foreclosed property in-house is presented in Section 4. Section 5 provides formal empirical tests of model predictions. The paper ends with a summary of the main findings. 


\section{A Model of Financial Distress for an Owner-Managed Project}

In this section we model a financially distressed owner-managed project. Figure 1 depicts the stages of financial distress. Conditional on a negative shock to project value, in the first stage the owner either defaults or uses available cash to make the current loan payment. Then, conditional on default, the game moves to a second stage in which the lender chooses to restructure or foreclose the loan. The third stage occurs if the loan is foreclosed. In this stage the lender chooses to manage the foreclosed asset in-house or sell the asset to an outside buyer.

\section{Figure 1 Here}

We will begin this section with a brief description of the model. Then the lender's payoffs are derived. These payoffs determine the conditions under which the defaulted loan is restructured versus foreclosed, and when the foreclosed asset is sold to an outside buyer versus managed in-house. Lastly, conditions for borrower default are derived.

\subsection{Model Set-up}

Consider a project financed by owner-manager equity and outside debt. Owner-manager liability is limited to her equity contribution. All agents are risk-neutral and the risk-free rate of interest is zero. The debt contract calls for payments of $\mathrm{P}_{0}$ at $\mathrm{t}=0$ and $\mathrm{P}_{1}$ at $\mathrm{t}=1$. At $\mathrm{t}=0$, the owner-manager has sufficient uncommitted liquidity so as to make the required payment, $\mathrm{P}_{0}$. The project's cash flows are realized at $\mathrm{t}=1$ and depend on two factors: the observable state of the economy at $\mathrm{t}=0$ and noncontractible investment made by the owner-manager at $t=0$. At $t=1$, the realized cash flows are distributed to the lender and owner-manager according to absolute priority.

The $\mathrm{t}=1$ cash flow is $\mathrm{V}+\mathrm{B}$ if project fundamentals are strong and the project is successful, and $\mathrm{V}-\mathrm{B}>0$ if project fundamentals are weak and the project is successful. Cash flow is 0 if the project is unsuccessful. The ultimate success of the project is not revealed until some time after $\mathrm{t}=0$ (but prior to $\mathrm{t}=1$ ). When project fundamentals are strong the borrower does not default. However, when they are weak, payoffs are such that it is rational for the owner-manager to consider default. The financial distress process depicted in Figure 1 presumes a weak economy with project value shock, B. To streamline the analysis we assume that the terminal debt payment, $\mathrm{P}_{1}$, is greater than $\mathrm{V} / 2$.

Non-contractible investment by the owner-manager affects project value through its "likelihood of success." The probability that the project is successful is $\rho, 0 \leq \rho<1$, where $\rho$ is chosen by the owner- 
manager with knowledge of the state of the economy. Non-contractible investment has a cost of $\mathrm{C}(\rho)$, which is increasing and convex as a function of $\rho$. The owner-manager makes her default-payment decision prior to making her investment at time $\mathrm{t}=0$. $^{2}$

Two related features of this model are (1) owner-managed projects are not financed with outside equity, and (2) debt restructurings involve debt forgiveness rather than debt-for-equity exchanges. Both of these features are observed in our sample of owner-managed projects with a single source of secured debt. The following discusses how the owner-manager's role in determining the probability of project success motivates the use of outside debt financing in the initial capital structure, as well as why distressed workouts involve debt forgiveness rather than debt-for-equity swaps.

In the formal model the costs of investment are exclusively borne by the owner-manager. Thus, $\mathrm{C}(\rho)$ can be thought of as the owner-manager's disutility of the effort she provides to maintain the asset. Investment effort distortions associated with raising outside capital are minimized when the difference between the contingent payoffs to the owner-manager are maximized; i.e., when the external capital provider holds a senior claim on the project's cash flows and the owner-manager is the sole residual claimant. ${ }^{3}$ In a weak economy the underinvestment problem is acute, which motivates the lender to consider a financial restructuring that improves the borrower's investment incentives. The outside capital provider, the lender, must scale back her claim in order to improve the manager's incentives to supply effort. The manager's incentives to supply effort are not improved by the lender taking an equity stake in exchange for debt forgiveness. ${ }^{4}$

Conditional on default, the debt is either restructured or the asset is sold to another ownermanager. The potential outsider buyer has wealth of $\mathrm{W}$ that can be used along with debt financing to

\footnotetext{
${ }^{2}$ This model is designed to capture the realistic possibility that exogenous factors affect the profitability of a project after the initial financing is sought. The agency problems associated with outside financing could be reduced by having the lender own the project until the state of the economy is revealed, and then sell a stake in the project to the owner-manager just prior to when the investment choice is made. However, forcing the owner-manager to have a stake in the project before the state of the economy is revealed may mitigate moral hazard problems associated with the likely (unmodeled) situation that the owner has some private information about the success of the project. To address this issue, the model could be complicated by introducing asymmetric information and requiring the manager to make an investment choice before the state of the economy is revealed and then again after the state of the economy is revealed.

${ }^{3}$ More generally, the model is designed to capture situations where it is inefficient for the owner-manager to have a very small equity stake in the project; i.e., situations where it is inefficient to separate ownership from management.

${ }^{4}$ Two important caveats are warranted. First, the outside capital provider's claim in this paper is referred to as a "debt contract." Since the cash flow is assumed to be zero when the project is unsuccessful, the financial contracts are simply a division of cash flow if the project is successful. If the payoff to an unsuccessful project was positive but less than the face value of the debt, then there would be a meaningful distinction between debt and equity claims, and distressed borrower incentives would be improved only with write-downs of the existing debt. The assumption that the cash flow is zero when the project is unsuccessful simply streamlines the exposition. Second, we have not shown that debt is an optimal contract in this setting. Outside debt financing provides better owner-manager investment incentives than outside equity financing. Innes (1990) shows that debt financing (1) provides superior incentives and (2) is optimal with risk neutral agents. Dewatripont, Legros and Matthews (2002) show optimality of outside debt financing in the presence of moral hazard holds under more general conditions.
} 
purchase the foreclosed asset from the lender. The incumbent owner-manager is assumed to have no meaningful wealth to inject into the project in a restructuring, i.e. the manager invests nearly all available wealth to purchase the asset. The manager only has sufficient liquid assets to make the required coupon payment.

The assumption that the existing manager has no meaningful wealth to contribute to a restructuring is made for two reasons. First, because the owner-manager is risk neutral and there is an underinvestment problem associated with outside financing, it is optimal for the owner-manager to contribute her entire wealth to the project at origination. Second, and more important, the implications for allowing the owner-manager to have modest amounts of wealth to contribute in a restructuring do not change basic conclusions of the analysis. Specifically, when the model is solved for the more general case where the existing manager has some level of wealth, it is shown that the outcomes depend on the difference between the existing manager's and outside buyer's wealth (see the Appendix). Thus, rather than specify the existing manager and outside buyer wealth, we normalize the existing manager's wealth to zero.

The level of W (sector wealth) and the size of the asset specific shock, B, are two of the three critical parameters that determine both the outcome in default (restructuring versus foreclosure) and the whether the borrower defaults in the first place. The third parameter, the management productivity of the outsider buyer relative to the distressed owner-manager, is introduced below.

\subsection{Owner-Manager Investment}

The expected payoff to the owner-manager is a function of the investment provided, the state of the economy, and the amount of debt due at $t=1$. There are two potential long-run project managers: the incumbent owner-manager or an outside owner-manager that acquires the project from the lender in foreclosure. Each has its own unique investment technology.

The amount of debt due at $\mathrm{t}=1, \mathrm{~F}$, depends on the situation. If the incumbent does not default, then $\mathrm{F}=\mathrm{P}_{1}$. If default occurs and the loan is restructured, then some debt is forgiven based on negotiations between the incumbent borrower and lender. If the project is foreclosed and sold to an outside buyer, the amount of debt against the project depends on the managerial efficiency of the new owner-manager.

Given a weak economy, the expected payoff to the owner-manager at $t=1$ is $\rho_{i}[V-B-F]-C_{i}\left(\rho_{i}\right)$, where $i=1$ indicates the incumbent owner-manager and $i=2$ indicates an outside buyer. For ease of 
analysis the investment technology is assumed to take the form $C_{i}(\rho)=\beta_{i} \rho^{2}$, where $\beta_{i}$ is scaled so that $\rho<1$ is satisfied. Based on this structure, it is straightforward to show that the optimal investment is

$$
\rho_{i}(F)=[V-B-F] / 2 \beta_{i}
$$

when the numerator is positive; otherwise, $\rho_{i}(F)=0$. Owner-manager investment depends on the size of her residual equity claim when the project is successful (as seen in the numerator) and her management efficiency (as seen in the denominator).

\subsection{Lender Payoffs From Restructuring and Foreclosure}

We now consider the lender's payoffs from a restructuring versus a loan foreclosure that results in an immediate sale of the asset to an outside buyer. Later, the lender is allowed to temporarily manage the foreclosed asset in-house before selling it to an outside buyer.

In a restructuring the lender is assumed to make a take-it-or-leave-it offer to the borrower. This occurs prior to the borrower making her coupon payment, $\mathrm{P}_{0}$, or her investment decision. The offer nullifies the original loan contract and stipulates the new amount of debt due at $t=1$. If the offer is accepted, no coupon payment is required and investment in the asset occurs based on the renegotiated debt payoff due at $\mathrm{t}=1$. If the borrower rejects the offer, the loan is foreclosed.

The lender's optimal offer is a new debt payoff amount, $F_{1}$, that maximizes

$$
\rho_{1}\left(\mathrm{~F}_{1}\right) \mathrm{F}_{1}
$$

subject to the owner-manager's participation constraint

$$
\rho_{1}\left(F_{1}\right)\left[V-B-F_{1}\right] \geq C_{1}\left(\rho_{1}\left(F_{1}\right)\right)
$$

The solution to the lender's maximization problem yields

$$
\mathrm{F}_{1}^{*}=(\mathrm{V}-\mathrm{B}) / 2
$$

and

$$
\rho_{1}\left(\mathrm{~F}_{1}^{*}\right)=(\mathrm{V}-\mathrm{B}) / 4 \beta_{1}
$$


A critical aspect of a restructuring is that the owner-manager maintains a significant share of the rents from the project. In other words, the participation constraint in equation (3) is not binding.

The payoff to the lender from foreclosure and asset sale depends on the characteristics of the potential buyer at the time of foreclosure - specifically, $\mathrm{W}$ and $\beta_{2}$. The most a potential buyer is willing to pay for the project is the market value of debt that can be borrowed against the asset plus her personal wealth, W, subject to a participation constraint. The maximum amount of debt that can be borrowed against the project at $\mathrm{t}=0$ by the potential buyer is $\rho_{2}\left(\mathrm{~F}_{2}\right) \mathrm{F}_{2}$, as stated in Equations (4) and (5), where $\rho_{2}\left(\mathrm{~F}_{2}{ }^{*}\right) \mathrm{F}_{2}{ }^{*}=(\mathrm{V}-\mathrm{B})^{2} / 8 \beta_{2}$. Thus, a potential buyer is willing to pay more for the project than the lender's expected payoff from a restructuring if

$$
\mathrm{W}+(\mathrm{V}-\mathrm{B})^{2} / 8 \beta_{2}>(\mathrm{V}-\mathrm{B})^{2} / 8 \beta_{1}
$$

The actual wealth contributed as equity by the outsider is potentially limited by the following participation constraint:

$$
\mathrm{W} \leq \overline{\mathrm{W}}=\rho_{2}\left(\mathrm{~F}_{2}{ }^{*}\right)\left[\mathrm{V}-\mathrm{B}-\mathrm{F}_{2}{ }^{*}\right]-\beta_{2}\left(\rho_{2}\left(\mathrm{~F}_{2}{ }^{*}\right)\right)^{2}
$$

Rearranging Equation (6) leads to Proposition 1.

Proposition 1. An outside buyer with wealth $W$ and investment technology parameter $\beta_{2}$ is willing to pay more for the financially distressed asset than the lender's payoff in restructuring if and only if

$$
W \geq \underline{W}=\operatorname{Max}\left\{\left(\frac{(V-B)^{2}}{8}\right)\left[\frac{1}{\beta_{1}}-\frac{1}{\beta_{2}}\right], 0\right\}
$$

and the participation condition in Equation (7) is satisfied.

See the Appendix for the proof of the proposition. Notice that foreclosure and asset sale dominates restructuring whenever $\beta_{2}<\beta_{1}$ (i.e., when the outside buyer is more efficient than the current owner at managing the project). When the outside buyer is less efficient than the incumbent at managing the asset, the necessary conditions expressed in equations (6) and (7) indicate that $\beta_{1}$ and $\beta_{2}$ must be such that $2 \beta_{2} / 3 \leq \beta_{1}<\beta_{2}$. If the outside buyer is extremely inefficient relative to the incumbent $\left(\beta_{1}<2 \beta_{2} / 3\right)$, the lender will always prefer restructuring over foreclosure and immediate sale, no matter how wealthy the outsider is. More generally, recognize that the level of wealth, W, required to make an 
offer for the asset is increasing in $\beta_{2}-\beta_{1}$, implying diminishing economic rents to the outside buyer as the difference in owner-manager efficiency becomes larger.

We wish to make three points regarding lender payoffs from reorganization versus liquidation. First, the model provides a different motivation than found in Shleifer and Vishny (1992) for selling assets to well-capitalized buyers. In Shleifer and Vishny (1992), well-capitalized buyers purchase financially distressed assets because these buyers face smaller debt overhang problems and therefore have better investment incentives than the financially distressed firm. In this model, the lender has the option to improve the financially distressed borrower's balance sheet and investment incentives by restructuring the debt. Because of this option, the lender only sells the asset to an outsider (rather than restructure the debt) when the outsider is willing and able to pay for a portion of the gains from improving investment incentives. Only sufficiently productive and wealthy outsiders are capable of paying for a sizeable portion of the economic rents in the project.

Second, the incumbent owner-manager captures the rents from improving investment incentives and avoiding foreclosure. The lender's inability to capture rents in a restructuring creates the potential for a foreclosure. Thus, in contrast to Bulow and Shoven (1978) and Stromberg (2000), where the bank lender is motivated to foreclose because wealth is transferred to other lenders in a restructuring, in this model inefficient liquidations can occur with only a single debtholder.

Third, conditional on default and the size of the project value shock B, the two factors that drive the liquidate versus restructure decision are the wealth of the outside buyer (W) and the management efficiency of the outside buyer relative to the incumbent owner-manager $\left(\beta_{2}-\beta_{1}\right)$. Liquidation occurs when the equity stake that an outsider is willing to contribute to the project is larger than gap between the value of the asset run by the incumbent and a less-skilled outsider. The size of the project value shock, B, plays a relatively unimportant role in the lender's restructuring-foreclosure decision at this point because it is exogenously given and is therefore sunk and common to all potential asset owners.

\subsection{Managing the Asset In-House}

The lender has the additional option of carrying the foreclosed asset in inventory rather than selling it immediately to an outside buyer. ${ }^{5}$ The lender may wish to carry the asset because he anticipates the industry will recapitalize in the near future, which implies increases in wealth and more

\footnotetext{
${ }^{5}$ U.S. banks are subject to only modest holding period limits when taking equity in exchange for debt forgiveness (James (1995)). We are aware of no such limitations for insurance companies.
} 
competition among outside buyers. Carrying distressed collateral in inventory is costly, however, since the lender does not have a comparative advantage in asset management. ${ }^{6}$

Formally, we assume that if the lender repossesses the asset at $\mathrm{t}=0$ he can manage it in-house until some point prior to $t=1$, at which time the asset is sold to an outside buyer. The cost of carrying the asset in inventory is K. For positive K, the lender only manages the asset when it perceives that the industry will recapitalize prior to $\mathrm{t}=1$; otherwise, he is better off foreclosing and selling the asset immediately.

Let the expected wealth of the future outside buyer equal $\mathrm{W}_{\mathrm{t}+1}$, which is assumed to be at least $\mathrm{W} .^{7}$ The assumption that $\mathrm{W}_{\mathrm{t}+1}-\mathrm{W}$ is non-negative appeals to the idea that industry wealth levels move toward a long-run equilibrium after a negative shock. In general, it may be that both higher $\mathrm{W}$ and lower $\beta_{2}$ entities emerge. For simplicity, we focus on W. Further assume that the outsider's participation constraint expressed in equation (7) is not binding at $\mathrm{t}=0$, which implies that the lender's payoff increases one-for-one with the wealth of the outside buyer.

Given this setting, foreclosure and delayed sale dominates restructuring at $\mathrm{t}=0$ when

$$
\mathrm{W}_{\mathrm{t}+1}-\mathrm{K}>\underline{\mathrm{W}}
$$

Foreclosure and delayed sale dominates foreclosure and immediate sale when

$$
\mathrm{W}_{\mathrm{t}+1}-\mathrm{K}>\mathrm{W}
$$

Thus, both (8) and (9) must hold simultaneously for a foreclosure and delayed asset sale outcome to possibly occur.

To characterize the set of outcomes in terms of outsider buyer wealth at $t=0$ (the time of default), we further assume that: (1) $\mathrm{W}_{\mathrm{t}+1}$ is increasing in $\mathrm{W}$, where both $\mathrm{W}_{\mathrm{t}+1}$ and $\mathrm{W}$ are continuous variables; and (2) $\mathrm{W}_{\mathrm{t}+1}-\mathrm{W}$ is decreasing in $\mathrm{W}$; i.e., the industry recapitalizes faster when industry wealth is low and assets are priced low relative to fundamentals.

These assumptions imply that there exists a unique $\mathrm{W}, \mathrm{W}=\widetilde{\mathrm{W}}$, such that $\mathrm{W}_{\mathrm{t}+1}-\mathrm{K}=\widetilde{\mathrm{W}}$. For $\mathrm{W}>(<) \widetilde{\mathrm{W}}$, it is the case that $\mathrm{W}_{\mathrm{t}+1}-\mathrm{K}<(>) \mathrm{W}$. Thus, for $\mathrm{W}>\widetilde{\mathrm{W}}$, immediate sale dominates delayed

\footnotetext{
${ }^{6}$ The lender's initial decision to provide debt financing reveals its desire to own a fixed claim against the asset rather than an equity stake in the project.

${ }^{7}$ The case where $\mathrm{W}_{\mathrm{t}+1}$ is greater than $\mathrm{W}$ is likely to occur because the shock to project value that leads to financial distress would generally adversely effect potential buyer wealth. When $\mathrm{W}_{\mathrm{t}+1}$ is less than $\mathrm{W}$, the lender never delays the sale of a foreclosed asset.
} 
sale. Conversely, if $\mathrm{W}<\widetilde{\mathrm{W}}$, equation (9) holds, implying the industry is expected to recapitalize fast enough for the lender to find it optimal to wait for a higher valued buyer to emerge.

Rational delayed sale requires that it also dominate restructuring. If $\widetilde{W}<\underline{W}$ when $W=\underline{W}$, delayed sales will never occur. This represents a case in which asset carrying costs are high. Thus, in this situation, for $\mathrm{W}<\underline{\mathrm{W}}$, a restructuring occurs. For $\mathrm{W}>\underline{\mathrm{W}}$ it will also be the case that $\mathrm{W}>\tilde{\mathrm{W}}$, so foreclosure and immediate sale occur. If, on the other hand, $\widetilde{W}>\underline{W}$, for all $\mathrm{W}$, foreclosure with delayed asset sale always dominates restructuring. This represents a case in which industry conditions are expected to be particularly robust in the next period. Thus, in this situation, for $\mathrm{W}<\tilde{\mathrm{W}}$, foreclosure and delayed sale occur, whereas foreclosure and immediate sale occur when $\mathrm{W}>\widetilde{\mathrm{W}}$.

The two cases identified above are extreme, in the sense that restructurings and foreclosures with delayed asset sales cannot both occur in a given market setting as a function of W. We would expect to commonly observe all three outcomes (restructuring, foreclosure-delayed sale, foreclosureimmediate sale) in the cross-section as a function of industry conditions. There does in fact exist an intermediate case that falls in between the two more extreme cases identified above. In this intermediate case it may be that foreclosure with delayed asset sale does not dominate restructuring at very low current wealth levels whereas, at somewhat higher current wealth levels, foreclosure with delayed sales dominates both restructuring and foreclosure with immediate sale.

More formally, we impose the following additional assumption: (3) There exists a unique W, 0 $<\mathrm{W}<\underline{\mathrm{W}}$, denoted as $\breve{\mathrm{W}}$, such that $\mathrm{W}_{\mathrm{t}+1}-\mathrm{K}=\underline{\mathrm{W}}$ when $\mathrm{W}=\breve{\mathrm{W}}$. Because $\mathrm{W}<\underline{\mathrm{W}}$ at the point at which $\mathrm{W}_{\mathrm{t}+1}-\mathrm{K}=\underline{\mathrm{W}}$, it immediately follows that $\breve{\mathrm{W}}<\widetilde{\mathrm{W}}$. This says that the indifference point between restructuring and foreclosure with delayed asset sale is less than the indifference point between foreclosure with delayed sale and immediate sale. Thus, as a function of current industry wealth, there exists a region where foreclosure with delayed asset sale is preferred to restructuring as well as foreclosure with immediate sale.

Furthermore, it follows that when $\mathrm{W}<\breve{\mathrm{W}}$, restructuring dominates both foreclosure with delayed asset sale and foreclosure with immediate sale. This final relation establishes the existence of a region where, as a function of current industry conditions, restructurings in addition to foreclosures with immediate or delayed sale can occur as a function of current industry wealth, W. These possible outcomes are summarized in the following proposition.

Proposition 2. Given assumptions (1)-(3) and a non-binding participation constraint, there exist a unique $\breve{\mathrm{W}}$ and $\widetilde{\mathrm{W}}, \breve{\mathrm{W}}<\widetilde{\mathrm{W}}$, such that for $\mathrm{W}<\breve{\mathrm{W}}$, a restructuring occurs; for $\breve{\mathrm{W}}<\mathrm{W}$ 
$<\widetilde{\mathrm{W}}$, a foreclosure and delayed sale occurs; and for $W>\widetilde{\mathrm{W}}$, a foreclosure with immediate sale occurs.

The proof of Proposition 2, together with visual representations of the possible lender-resolution regimes discussed in this section, are provided in the Appendix.

\subsection{Borrower's Decision to Default}

The decision to default depends on whether foreclosure or restructuring is anticipated as a result of default. When a restructuring is anticipated the borrower defaults since debt is forgiven. If the borrower defaults and the lender forecloses, the incumbent's payoff is zero. Consequently, if the incumbent anticipates that a default will result in foreclosure, she makes the contracted payment of $\mathrm{P}_{0}$ to avoid default if and only if her equity position from continuation exceeds $\mathrm{P}_{0}$. Proposition 3 states the default condition.

Proposition 3. Default followed by foreclosure occurs when the owner-manager anticipates foreclosure in default and $\mathrm{B}>\mathrm{B}^{*}$, where $\mathrm{B}^{*}=\mathrm{V}-\mathrm{P}_{1}-2 \sqrt{\beta_{1} \mathrm{P}_{0}}$

The critical default value, $\mathrm{B}^{*}$, depends intuitively on model parameters and is derived in the Appendix. Clearly, the larger the shock to project value, the less likely it is that the owner-manager makes the current debt payment necessary to avoid default. Note that this critical value does not depend on outside investor parameters $\mathrm{W}$ or $\beta_{2}$, since option-based default is specific to incumbent circumstances. This does not imply that the default decision is independent of $\mathrm{W}$ or $\beta_{2}$, however, since the outcome of default depends on $\mathrm{W}$ relative to $\breve{\mathrm{W}}$, where $\breve{\mathrm{W}}$ is a function of the productivity of the outside investor.

\subsection{Model Summary and Empirical Implications}

The model indicates that the shock to project value (B) and the liquidity of outside buyers (W) largely drive the outcomes of the financial distress. Figure 2 takes the fully developed model and depicts realizations of $\mathrm{B}$ and $\mathrm{W}$ that result in: (a) no default (continuation), (b) default followed by a loan restructuring, (c) default followed by foreclosure and immediate asset sale, (d) default followed foreclosure and delayed asset sale.

Figure 2 Here 
When the shock to project value is relatively small, such that $\mathrm{B}<\mathrm{B}^{*}$, the owner-manager's continuation value is positive. However, if industry wealth is simultaneously low (W $<\breve{\mathrm{W}}$ ), the borrower strategically defaults knowing that she can extract concessions through a debt restructuring. If, on the other hand, $\mathrm{W}>\breve{\mathrm{W}}$, the borrower does not default. Industry wealth is sufficiently high so that foreclosure is valued more highly than a debt restructuring by the lender, which precludes a strategic default from occurring.

When $\mathrm{B}>\mathrm{B}^{*}$, the owner-manager's continuation value is negative and an option-based default occurs. If industry wealth is low $(\mathrm{W}<\breve{\mathrm{W}})$ the lender restructures the loan because foreclosure would require selling the asset at a significant discount to its fundamental value. Thus, a loan restructuring occurs in all cases in which industry wealth is low, regardless of the size of the shock to project value. When industry wealth is sufficiently high $(\mathrm{W}>\breve{\mathrm{W}})$, the owner-manager defaults and foreclosure occurs. Foreclosed asset sale is delayed when industry wealth is currently at moderate levels and is expected to increase in the near future $(\breve{\mathrm{W}}<\mathrm{W}<\widetilde{\mathrm{W}})$. Foreclosed asset sale is immediate when industry wealth is currently high $(\mathrm{W}>\widetilde{\mathrm{W}})$.

The level of the boundary whichh defines the restructuring region, $\breve{W}$, depends on the productivity of the incumbent owner-manager relative to that of the potential outside buyer. Incumbents who manage specialized assets may have a significant advantage over potential outside buyers, implying that $\beta_{2}-\beta_{1}$ is relatively large. A greater disparity in management skill causes the $\breve{W}$ boundary to shift up, increasing the likelihood of a restructuring.

Outcomes also depend on the lender's carrying cost parameter, K, which is implicit in the location of both $\widetilde{\mathrm{W}}$ and $\breve{\mathrm{W}}$. An increase in carrying costs results in a parallel downward shift in $\widetilde{\mathrm{W}}$ to decrease the likelihood of a foreclosure-delayed sale outcome relative to a foreclosure-immediate sale outcome. A simultaneous upward shift in $\breve{\mathrm{W}}$ also occurs to account for the fact that $\mathrm{W}_{\mathrm{t}+1}$, and hence $\mathrm{W}$, must increase to offset the increase in $\mathrm{K}$. This increases the likelihood of a restructuring outcome relative to a foreclosure-delayed sale outcome. Thus, when $\mathrm{K}$ increases, the foreclosure-delayed sale region is squeezed from both sides due to a decrease in $\widetilde{W}$ and an increase in $\breve{W}$. If the increase in $K$ is large enough, the foreclosure-delayed sale region disappears altogether and only restructurings or foreclosure-immediate sales occur.

The analysis assumes that the distressed borrower has no wealth to contribute in a restructuring. When this assumption is relaxed (see the Appendix) the implications are twofold. First, when the borrower has wealth to contribute to a restructuring, the minimum level of outside buyer wealth 
required for the lender to prefer foreclosure over restructuring is higher; i.e. $\underline{\mathrm{W}}$ and therefore $\breve{\mathrm{W}}$ increase. Further, the borrower extracts fewer rents in a restructuring when she contributes wealth. In general, to the extent that the incumbent is more efficient at operating the asset than outsiders, the existence of incumbent borrower wealth is economically desirable.

Second, since the distressed borrower may be forced to commit wealth in a restructuring, the incentives to default strategically are muted. When the borrower has no wealth to contribute, restructurings reduce the debt obligation. When a restructuring is anticipated by the borrower, it dominates continuation for all values of B. If the borrower has available wealth, and competition forces her to contribute some of that wealth in a restructuring, then restructuring is not as attractive. Thus, for small values of $B$, strictly less than $\mathrm{B}^{*}$, the borrower finds it optimal to continue rather than default when a restructuring is anticipated.

One interesting implication of the model is that financially distressed projects that are foreclosed will, on average, have experienced worse pre-default operating performance than projects that are restructured. That is, the average value of $\mathrm{B}$ conditional on foreclosure is greater than the average value of B conditional on a restructuring. Stromberg (2000) examines a set of bankrupt Swedish firms and finds that firms that are liquidated in bankruptcy have worse pre-bankruptcy performance than firms that are reorganized in bankruptcy. This finding is interpreted as evidence that poorly managed firms are more likely to be liquidated and sold to a better manager. The link between project performance and the probability of liquidation is potentially very different in our model. Endogenous borrower default implies that poorly performing loans may be liquidated because borrowers with low continuation values do not find it rational to avoid a default that leads to liquidation.

Because the size of the project shock, B, and the level of sector wealth, W, are often correlated, our model suggests that asset firesale discounts will occur and that the discounts will vary over time as $\mathrm{B}$ and $\mathrm{W}$ vary over time. When $\mathrm{B}$ is high and $\mathrm{W}$ is low, borrowers will default because the continuation value is negative, and will significantly underinvest in the asset. This leads to increased levels of foreclosure with assets arriving in poor operating condition. There will be incentives for the lender to carry these assets in inventory to avoid selling into a distressed market, but carrying costs are generally significant. Consequently, the lender will sell certain (probably better quality) assets at a healthy discount to fundamental value to avoid the costs of carry. Then, as the market recovers, the less marketable assets will be sold. These assets will also be sold at significant discounts to fundamental 
value after accounting for capital improvements and other related investment costs incurred over the holding period.

Time-varying asset and industry conditions thus imply three relevant empirical predictions. First, as discussed above, firesale discounts are predicted to vary as a function of external conditions as of the time of foreclosure. For example, foreclosure cohorts with high B and low W outcomes are predicted to result in higher discounts, realized at the time of asset sale. Second, the lender is predicted to function as a market-maker in the market for distressed real assets through the inventory management process, and thus addresses "order" imbalances caused by liquidity problems in the market. Third, as a result of this inventory management function, we would expect to see smaller differences in the size of asset firesale discounts measured as of the time of asset sale. This follows because asset sale timing is endogenously determined by the lender. At a particular point in time, with current wealth level $\mathrm{W}$, the asset inventory will contain various foreclosure cohorts. The sales decision considers the tradeoff between the cost of carrying the asset in inventory (which causes a reduction in its net value) with immediate sale (where wealth levels and hence the gross sales price are expected to continue to improve in the future). This tradeoff together with timing discretion smoothes variation in measured sale discounts over time.

Further unique empirical predictions implied in our model follow from endogenous default in relation to the combined effects of project value shock magnitudes $(B)$, relative management efficiency $\left(\beta_{1}, \beta_{2}\right)$ and sector wealth $(\mathrm{W})$. Conditional on foreclosure, the timing decision to sell foreclosed assets is predicted to depend on current and expected sector wealth levels in addition to the management efficiency of outside buyers. Furthermore, when the incumbent borrower is efficient at operating the asset, we predict that the restructuring-foreclosure outcome depends uniquely on the size of the shock, $\mathrm{B}$, in addition to wealth levels and potential outside owner efficiency. In our model, like Stromberg (2000), relative management efficiency also plays a role in the restructuring-foreclosure outcome; however, our model includes a well-defined role for outside investor wealth and endogenous default.

Finally, our model is capable of providing unique explanations for time-series patterns of restructuring-foreclosure outcomes in which project value shock magnitudes and wealth levels change over time. For example, other models of financial distress cannot simultaneously explain why, when large systematic shocks occur to a sector, foreclosure tends to occur with greater frequency (optionbased default occurs and the lender holds assets in inventory), but when value and wealth levels begin to recover, restructuring is the more frequent outcome (strategic default occurs in anticipation of a restructuring). 


\section{Data Description and Market Overview}

\subsection{The Distressed Loan Sample}

Model implications are examined using a data set of financially distressed commercial real estate loans originated by a large multi-line life insurance company. Commercial real estate loan data are, for several reasons, useful for testing the model implications. First, commercial real estate assets are typically owner-managed with a single source of secured debt financing. Managers play an important role in the success of commercial real estate assets, as discussed by Williams (2001). Second, the sample period covers the major commercial real estate downturn and recovery that occurred during the late 1980s to middle 1990s. This provides a large number of defaulted loan observations and significant variation in industry conditions across time. Third, commercial mortgages are issued with high frequency and contracting is relatively homogenous, which improves statistical reliability. Fourth, insurance companies have considerable discretion in their negotiations with distressed borrowers and in timing the sale of foreclosed assets.

The data set includes loans originated between 1974 and 1990. The data indicate whether or not a borrower ever incurred a payment default, which is defined as a loan being classified as 90 days or more delinquent. Our data source electronically recorded the status of financially distressed loans from 1986-95. A total of 2589 commercial real estate loans were originated by the insurance company from 1974 to 1990 . Of these 2589 loans, 807 experienced a payment default at some point during the 198695 time-frame. This equates to a cumulative default rate of 31.1 percent. $^{8}$

Loan status indicators identify the relevant stages of financial distress as: (1) restructured, (2) foreclosed, (3) sale of foreclosed asset. A total of 631 commercial real estate loans were either restructured $(\mathrm{N}=289)$ or foreclosed $(\mathrm{N}=342)$ during the 1986-95 time period. ${ }^{9}$ This implies that 176 of the defaulted loans (807 minus 631) were neither restructured nor foreclosed. Thus, of the 807 defaulted loans, 35.8 percent were initially restructured, 42.4 percent were foreclosed without ever being restructured, and 21.8 percent avoided either a restructuring or a foreclosure (typically by recovering). Of the 289 restructurings, 70 were eventually foreclosed for a total of 412 foreclosures. The lender sold 270 of the 412 foreclosed loans prior to year-end 1995.

\footnotetext{
${ }^{8}$ There is left-censoring as well as right-censoring of the data that affect the analysis. Some loans that were originated before 1986 experienced financial distress prior to the time in which loan status indicators were available. Availability of left-censored data would have increased the total number of defaulted loans and the lifetime default rate. There is also the possibility that some loans defaulted after 1995, which marks the end of our sample period. Our judgment is that left and right censoring do not present significant statistical issues, as commercial real estate markets were relatively healthy over the 1974-85 and post-1995 time periods (i.e., during the periods prior to the market crash and after the recovery).

${ }^{9}$ Recall that there are 807 loan defaults in the data. A total of 631 restructured or foreclosed loans implies that 176 loans temporarily experienced financial distress and were resolved prior to a restructuring or a foreclosure.
} 
Detailed cash flow data are available on all restructured and foreclosed loans, and include all loan fundings and borrower payments. In the case of restructured loans, the data show any reductions in contractually specified payments. In the case of foreclosed loans, an estimated asset value (transfer value) is assigned to the property at the time of foreclosure. All revenues and expenses realized during the in-house asset ownership period as well as the realized sales price at the time of asset sale are also available.

A review of the data and follow-up conversations with the lender provide information about the nature of the restructurings in financial distress. Restructured loan status codes and cash flow patterns indicate that the lender never took back an equity stake from a financially distressed borrower in return for reducing the loan balance. Instead, restructurings were simple write-downs. This is consistent with the model setting where restructurings must involve loan write-downs (without equity exchanges) in order to improve non-contractible investment incentives. The data further indicate that most defaults occurred prior to the maturity date of the loan. In these cases, debt restructurings did not typically extend maturity. Rather, a vast majority of the restructured loans were write-downs that lowered the required payments and effectively reduced the loan balance.

\subsection{The Commercial Real Estate Downturn and Recovery}

A large decline in US commercial real estate values occurred in the late 1980s and early 1990s. This largely happened because of overbuilding and resulting credit problems that limited financing availability for borrowers (see Fergus and Goodman (1994), Peek and Rosengren (1994), Brown (2000)). Figure 3 traces the value of a $\$ 100$ position invested in the National Association of Real Estate Investment Trusts (NAREIT) Equity REIT Price Index and the REIT Rent Index from 1982 through the end of 1996. ${ }^{10}$ The REIT Rent Index is the product of the Equity REIT Price Index and the dividend yield on that index. Since REITs are required to pay a large proportion of their earnings as dividends, the time variation of the REIT Rent Index should closely approximate the time variation in rents paid on the commercial real estate held by the firms in the Index.

\section{Figure 3 Here}

Figure 3 shows that REIT prices declined by approximately 30 percent from their peak at yearend 1986 to a low at year-end 1990. After the bottom, REIT asset prices increased significantly. In

\footnotetext{
${ }^{10}$ Equity REITs are non-taxed, exchange-traded firms that hold equity positions in commercial real estate assets.
} 
comparison, rent levels peaked in early 1987 and more or less held up through early 1990. Rents then dropped significantly in late 1990 and "bumped along the bottom" through early 1994 before beginning to increase. Thus, prior to 1987, prices and rents correlate closely, whereas prices and rents diverge after 1987 with prices leading rents by several years. ${ }^{11}$

The property type underlying each loan proxies for cross-sectional variation in the shock to project fundamentals (B). Table 1 shows peak-to-trough percentage changes in NCREIF index property values for the four core property types over the sample period. ${ }^{12}$ The decline in property values is smallest for apartment properties and greatest for office properties. These outcomes reflect differences in economic fundamentals: apartment property was the least overbuilt of all property types during the sample period, whereas office property was the most overbuilt. ${ }^{13}$

\section{Table 1 Here}

Property type and asset size proxy for differences in the asset's sensitivity to management quality. For example, apartment property tends to be generic and therefore not particularly management sensitive. In contrast, hotel is the most management sensitive property type in the data. Larger assets tend to be more complex to operate than smaller assets, so are more sensitive to management quality. Table 2 shows that size and property type are correlated. Apartment and industrial property tend to be the smallest of the property types, whereas hotel and office properties tend to be the largest.

\section{Table 2 Here}

\footnotetext{
${ }^{11}$ The lead-lag phenomena is largely due to the lagged information content of property rents together with large movements in fundamentals during this time period. Long-term leases are used to contract on space in commercial real estate markets. This means that current rent levels are weighted averages, reflecting current and historical spot rents. When changes to spot rents are large, current rent levels will be a lagging indicator of economic fundamentals.

${ }^{12}$ The NCREIF index is composed of directly held (non-exchange-traded) commercial real estate primarily belonging to the four core property types (office, industrial, retail, multi-family).

${ }^{13}$ There are also differences in price changes by geographical region or state. These differences are less pronounced than by property type. Furthermore, it is difficult to interpret these differences, as different regions experienced shocks at different points in time, whereas price movements by property type were contemporaneous with one another. Finally, different regions or states experienced demand as well as supply shocks that caused variation in the data. At the aggregated property type level, it was almost exclusively supply shocks that explain comparative variation in prices. Altogether, these factors cause us to focus on property type rather than geography as proxies for cross-sectional variation in the size of the project shock, B.
} 


\subsection{Commercial Mortgage Contracting and State Foreclosure Laws}

There is considerable uniformity in commercial mortgage contracting. All of the loans we analyze are fixed-rate, fixed-payment mortgages with non-recourse clauses that limit the borrower's liability to equity value embedded in the secured collateral. The secured collateral in all cases is improved real estate. Many of the loans, especially those that were originated after 1980, are callprotected with maturities in the 5-15 year range. Loans are typically partially amortizing with amortization periods of 15-30 years. For example, a loan may have a 10-year term-to-maturity in which payments fully amortize over a 25 -year time period.

A vast majority of the loans analyzed were originated at loan-to-value (LTV) ratios of between 71 and 75 percent. We find almost no variation in LTV ratio by property type. Further analysis indicates that LTV ratios at loan origination for restructured and foreclosed loans are similar to LTV ratios at origination for all originated loans. This suggests that economic or manager-specific factors, and not variation in financial structure as measured by LTV ratio, are the primary cause of financial distress.

State foreclosure laws govern the relationship between the lender and the borrower in a secured commercial real estate loan transaction, and ensure that an absolute priority ordering of creditors is observed (see Warren (1987)). ${ }^{14,15}$ Federal law as related to Chapter 7 or 11 bankruptcy provisions is typically relevant only when a particular mortgage transaction is part of a larger bankruptcy proceeding involving numerous assets and transactions. Only a small percentage of restructured or foreclosed loans (just over 5 percent of the sample) are part of a Chapter 11 bankruptcy proceeding. ${ }^{16}$

\subsection{Comparison to Industry Data}

Because our mortgage loan sample comes from a single commercial real estate lender, a large life insurance company, we are concerned whether our data are representative of the industry as a whole. To assess this issue, we have compared our data to industry data across a number of dimensions. As a first step, it is worth mentioning that the over the 1974-1990 sample period,

\footnotetext{
${ }^{14}$ As Warren (1987) states: "State collection law is a system in which one creditor can isolate the debtor's default and enforce repayment...The presence of state law rank ordering is that no claim is extinguished...the [state law] system streamlines the collection operation to ensure that the creditor can be the first to collect if the debtor's circumstances improve."

${ }^{15}$ State foreclosure laws are classified as either judicial or power-of-sale. The judicial law process is somewhat more bureaucratic and time consuming than the power-of-sale process (see Clauretie and Herzog (1990)) and Ciochetti (1997)). Of the 631 restructured and foreclosed loans, 183 were governed by judicial foreclosure law states and 448 by power-ofsale foreclosure law states.

${ }^{16}$ Baird and Jackson (1988) note that, “...under existing law, bankruptcy courts traditionally refuse to entertain a bankruptcy case involving a corporate debtor in which there was only one creditor." This suggests that bankruptcies that occur in the data involve a number of creditors and assets that are outside the data set.
} 
insurance companies were the largest single source of permanent commercial real estate loans in the U.S., with a market share in excess of 50 percent.

Our data are obtained from a prominent insurance company, which, according to the American Council of Life Insurers (ACLI), originated approximately 10 percent of all classified insurance company loans during the sample period. This placed the firm among the top three commercial real estate lenders in the industry. Table 3 contains a comparison between the industry and the sample along several dimensions, and shows very little difference in average loan size, average loan-to-value ratio, and average debt service coverage ratio at issuance. There are differences by property type, in which our sample is weighted more heavily toward apartment and industrial property than the industry, and less heavily toward retail, office and hotel property. We have also examined the regional distribution of loans (not reported in the table). With the exception of one region (Mid-Atlantic), we found only small differences between our sample and industry data with respect to geography (less than four percent differences as a percentage of the total, none of which were statistically different from one another).

\section{Table 3 Here}

We have also compared cumulative loan default rates using ACLI data contained in Esaki and Goldman (2005). Their analysis shows a cumulative default rate of 18.4 percent for loans originated between 1974 and 1990. This compares to a cumulative default rate of 31.1 percent for loans in our sample. Further comparison indicates that cumulative default rates by year of loan origination are higher in our sample than for the industry in each and every year from 1974-1990. This suggests that loans in our sample were riskier than at the industry level. It is possible that micro-locations of collateral property or borrower characteristics resulted in consistently riskier loan pools. However, discussion with knowledgeable industry professionals indicate that insurance companies often underreport defaults in their loan portfolios, as ACLI data are based on self-reported numbers supplied by firms that are required to set aside additional capital for those defaulted loans. This is in contrast to our data, which were collected after the fact and which we believe fully account for distressed loan occurrence. Consequently, with respect to reported frequencies of loan default, there are reasons to suspect the quality of the industry data in relation to our sample.

Finally, we have compared the outcomes of financial distress to ACLI industry data as reported in Esaki and Goldman (2005). Their data indicate that, based on first-time default activity, 52 percent of loans are liquidated, 25 percent are restructured, and 23 percent recover. This compares to 42 
percent of loans that are liquidated in our sample, 36 percent that are restructured, and 22 percent that recover. According to ACLI data, of loans that are initially restructured, 27 percent are ultimately liquidated, whereas 24 percent are liquidated in our sample. Thus, these data indicate that outcomes of financial distress are generally comparable, where there is a somewhat lower percentage of liquidated loans in our sample. We believe that this difference is at least partly explained by the higher proportion of apartment loans in our sample, which, as will be discussed in the next section, resulted in more restructurings than loans collateralized by other property types.

Altogether, these comparisons suggest that our mortgage loan sample has characteristics that are broadly similar to the industry. The data are particularly comparable at the time of origination and in terms of the outcomes of financial distress, which are the focus of the analysis that follows.

\section{Descriptive Data Analysis}

\subsection{Default Frequencies, Restructuring-Foreclosure Outcomes, and the Timing of Foreclosed Asset Sales}

To begin the formal empirical analysis, Table 4 displays defaulted loans by year of origination and year of onset of financial distress. The table shows that 807 of 2589 loans experienced financial distress during the 1986-95 time period, for a cumulative lifetime default rate of 31.1 percent. Annual default rates are persistently high during the 1986-90 time period, and peak 1991 at 6.3 percent (as seen in the total row near the bottom of the table). Default rates then decline quickly after the 1991 peak.

\section{Table 4 Here}

The table also shows the time-series of indexed REIT prices to provide a sense of industry liquidity and asset market fundamentals. REIT prices indicate deteriorating fundamentals in the late 1980s, with a bottom occurring in 1990 or shortly thereafter, followed by stabilized and improving market conditions. Defaults rates are seen to correlate closely with market conditions as proxied by REIT prices.

These results can be interpreted in the context of the model. High lifetime rates of default during our sample period suggest that property value shocks were both large and systematic. Furthermore, high default rates in the face of deteriorating market conditions suggest low continuation values in the pre-1992 time period. The decline in default rates after 1991 coincide with improving 
market conditions, implying lower B (project value shock), higher W (industry wealth) values. This in turn suggests movement into the loan continuation region depicted in Figure 2.

Table 5 documents that a total of 342 loans were foreclosed and 289 loans were restructured in response to borrower default. The relatively high proportion of foreclosed loans may seem surprising given the simple capital structures and relative transparency of commercial real estate assets. Indeed, Gilson, John and Lang (1990) find that restructuring is more likely with firms that possess more tangible assets, more bank debt, and simpler capital structures. The frequency of foreclosure outcomes is less surprising in the context of our model, which emphasizes non-contractable owner-manager investment, industry wealth effects, and asset inventory management by the lender. ${ }^{17}$

\section{Table 5 Here}

The data in Table 5 are broken out by decision year, defined as the year in which the restructuring-foreclosure decision was made. The striking result is that the lender was more likely to foreclose (restructure) defaulted loans when market conditions were deteriorating (improving) and default rates were increasing (decreasing). Specifically, during the 1986-90 time period, only 38 percent of the distressed loans were restructured, while during the 1991-1995 period the restructuring rate increases to 56 percent. This difference is statistically significant at the $1 \%$ level. We will attempt to explain this result after briefly reviewing some foreclosed asset sale data.

Table 6 shows asset sale timing decisions conditional on loan foreclosure. The table presents: (1) the number of loans that were foreclosed during the year, (2) the number of properties sold during the year, (3) the number of properties obtained through foreclosure that remain in inventory at the end of the year, (4) the average number of months the asset was held in inventory before the property was sold, and (5) the propensity of the lender to sell foreclosed properties.

\section{Table 6 Here}

As noted earlier, there were 412 mortgage foreclosures during our sample period, with 270 foreclosed asset sales. Foreclosure activity peaked in 1991 and 1992, which roughly corresponds to the market trough of 1990-91 (the data indicate it takes 18 months on average to move from the onset of

\footnotetext{
${ }^{17}$ Riddiough and Wyatt (1994) and Wang et al. (2002) also provide models that explain the co-existence of workout and foreclosure in mortgage markets. Riddiough and Wyatt focus on unobservable lender foreclosure costs and signaling with multiple borrowers to explain why a lender might prefer costly foreclosure outcomes. Wang et al. focus on borrower costs of default and screening costs incurred by the lender to distinguish between strategic and liquidity defaults.
} 
financial distress to loan foreclosure). Asset inventory peaks at year-end 1992, as foreclosure activity began to slow after 1992 and asset sales increased dramatically in 1993.

Asset sale propensities increase to over 30 percent in both 1993 and 1994, which correspond to a stabilized and improving commercial real estate asset market with substantial amounts of liquidity injected by REITs and other opportunistic investors. Average ownership period data (seen in column (4)) indicate that the properties sold in 1993 and 1994 were held in inventory for a relatively long period of time- -31 and 27 months, respectively. This supports the idea that the lender waited until the sector recapitalized to sell assets that, presumably, would have been sold at depressed prices prior to 1993. Further analysis of the timing of the sale of foreclosed assets is presented in the following section.

We are now in a position to address the time-varying restructuring-foreclosure relation noted in Table 5. Given that the market for foreclosed assets was weak during the downturn and shortly after the market hit bottom, one might expect the lender to prefer restructuring over foreclosure during that time. The data in Table 5 show the opposite occurred-foreclosure happened more frequently than restructuring. This result can be explained by endogenous borrower default. During a downturn, the distribution for B (the project value shock variable) moves to the right and borrowers do not find it optimal to continue to make the loan payments required to avoid foreclosure. As a result, a greater proportion of defaulted loans are foreclosed.

Later in the sample period the lender restructured defaulted loans when default rates were declining and the lender appeared to have a ready market for foreclosed assets. Better market conditions imply that the distribution of B values moves inward, causing borrowers to prefer continuation over foreclosure. This results in a simultaneous drop in the default rate and increase in the restructuring rate as (1) more borrowers find it optimal to continue to make their payments, and (2) the borrowers that default often do so strategically because they anticipate restructuring. ${ }^{18}$

Other explanations for why more loans were restructured when the market for distressed assets was stronger would require that the lender's relative gains from a restructuring increase for smaller B shocks. In our model there is no relation between the lender's gain from restructuring versus foreclosure and the size of B. Liquidation occurs when the equity stake that an outsider is willing to contribute to the project is larger than the gap between the value of the asset run by the incumbent and

\footnotetext{
${ }^{18}$ This finding may be stronger than the tables indicate, given the existence of an unavoidable lag between the time the foreclosure decision is made and the ultimate sale of the asset. Specifically, the lender became more likely to restructure defaulted loans starting in 1991, while it did not greatly increase the sales of foreclosed assets until 1993. Given that the average ownership period for foreclosed real estate is over two years, it is entirely possible that as real estate markets began to recover in 1991 and 1992, the lender decided to sell foreclosed assets. However, the decision to sell foreclosed assets did not result in completed sales until some time later.
} 
a less-skilled outsider. Put another way, the size of the project value shock is exogenous and hence common to all potential asset owners.

In summary, our initial analysis of the time series of foreclosed asset sales and default outcomes (foreclosure versus restructuring) is consistent with model predictions. Assets obtained through foreclosure during the late 1980s and early 1990s were managed internally and then sold when the industry recapitalized in the later part of the sample period. Consistent with endogenous default as shown in the model, a smaller proportion of defaulted loans were restructured when the lender did not have a strong market for commercial real estate assets but the borrowers experienced large project value shocks.

\subsection{Lender Capital Expenditures on Foreclosed Properties}

The data allow us to measure capital expenditures incurred by the lender during the foreclosure-asset ownership period. Commercial real estate capital expenditures consist of major property maintenance expenses (such as replacing a roof), any redevelopment costs incurred to reposition the asset in the market, tenant improvements, and leasing commissions. Capital expenditure and inventory ownership period data are presented in Table 7, where we provide detailed breakouts by property type, original loan size, and foreclosure year.

\section{Table 7 Here}

Monthly capital expenditures over the lender's foreclosed asset ownership period are first summed and then divided by the asset's sale price to produce a total capital expenditure percentage. Average total capital expenditures are 14.2 percent of the asset's sale price. The average ownership period is 2.3 years, which implies annualized capital expenditures of 6.2 percent on average. This compares to annual capital expenditures of 1.5 to 2 percent on average made by non-distressed owners of commercial real estate (Fisher, et al. (2001)). ${ }^{19}$ Thus, as a percentage of asset sales price, capital expenditures made by the lender on foreclosed assets were three to four times the level of capital expenditures made by non-distressed property owners.

The break-down in capital expenditures by property type shows that apartments (a low-shock sector) had relatively low levels of annualized capital expenditures, whereas office (a high-shock

\footnotetext{
${ }^{19}$ Fisher et al. (2001) study apartment property, and find economic depreciation rates of 2 percent per year on average. Based on personal correspondence with William Wheaton, property types other than apartment have slightly lower annual rates of economic depreciation, somewhere in the 1.5-2.0 percent range.
} 
sector) had the highest levels of capital expenditure. When we break out capital expenditures by the year of foreclosure, we find that total capital expenditures and time-in-inventory during the 1986-90 time period are more than double that of the later period. These findings imply that significant investment was required on foreclosed assets when market conditions were especially poor, while the lender also delayed sale of foreclosed assets until market conditions improved.

The capital expenditures made by the lender on foreclosed assets thus provide direct evidence of underinvestment by financially distressed owners of commercial real estate, and hence that foreclosed assets arrive in particularly poor condition. ${ }^{20}$ The additional capital expenditures made by the lender potentially come from two sources. First, consistent with model predictions, the financially distressed borrower may have rationally deferred regular maintenance of the property prior to defaulting on the loan, knowing that the continuation value was low and the probability of foreclosure was high. This is consistent with the finding that underinvestment on foreclosed assets is more severe in large shock sectors.

Second, changing market conditions might have required a large capital outlay to reposition the property to maximize its value. Again, a financially distressed property owner would have limited incentives to make a significant investment in the property, since the benefits to reinvestment may be disproportionately shared with the lender. As evidence that capital expenditures were made to redevelop or reposition certain assets, of the 269 sold assets for which we have data, 67 incurred capital expenditures in excess of $20 \%$ of the asset sale price, 26 had capital expenditures in excess of $40 \%$ of the sale price, and 3 incurred costs in excess of $100 \%$ of the sale price.

These findings support evidence presented in Asquith, Gertner and Scharfstein (1994) that firms reduce their capital expenditures following financial distress. Our evidence of underinvestment is somewhat more direct, in that we observe the change in capital expenditures when the asset is transferred to a well-capitalized owner.

\subsection{Firesale Discount Estimates}

Asset sale decisions by the lender are endogenous in our model, and the model predicts that assets will typically be sold at discounts to their fundamental value. A unique prediction of the model

\footnotetext{
${ }^{20}$ Some of the capital expenditures could be explained by inefficient investment decisions made by the lender. It is doubtful, however, that lender inefficiency could produce such a large gap in capital expenditures if there were no underinvestment by the borrower to begin with. It is also doubtful that the lender would repeatedly make capital expenditures on foreclosed assets once it recognized its own management inefficiency (that is, it would prefer to simply sell assets as-is to more efficient outsiders).
} 
is that the magnitude of the discount primarily depends on market conditions at the time of foreclosure rather at the time of asset sale.

A large negative shock will cause borrowers to walk away from lower quality assets (that have negative continuation value), with assets arriving in poor condition. Immediate sale will be especially costly because wealth levels are currently quite low. Carrying costs related to operating and repositioning the asset will be high, which offsets expected gains from selling later at higher wealth levels. The effects of sector illiquidity experienced at the time of foreclosure therefore linger throughout the asset inventory period, and are not eliminated by improved market conditions. In contrast, repossessed assets that arrive when market conditions are not as severe are predicted to sell more quickly, with lower resulting carrying costs, and at prices closer to fundamental value.

Because of the endogeneity of the asset sale decision, in which incremental carrying costs are traded off with expected gains in future wealth levels, firesale discounts are predicted to show less variation when measured at the time of sale. At any point in time a variety of foreclosure-year cohorts will exist in the inventory, in which sales are made from that inventory mix. Older assets that were repossessed when market conditions were weaker will sell at larger discounts to fundamental value and younger assets that were repossessed when market condition were stronger will sell at smaller discounts. The rate of sales of older assets will increase as market conditions improve, with a smaller proportion of newly foreclosed asset sales (since fewer foreclosures occur when shocks are smaller). The net effect is that asset sale discounts are smoothed over time when measured at the time of sale.

In this section we empirically estimate firesale discounts and how those discounts vary over time as a function of market conditions. To measure these discounts we compare the asset sale price to the transfer value, which is the lender's estimate of the asset's fundamental value at the time of foreclosure. To enhance the accuracy of the comparison, we adjust the sales price to account for capital expenditures by the lender as well as for changes in general market conditions that occurred over the asset inventory holding period. Table 8 contains our empirical results for the sample of 270 foreclosed asset sales.

\section{Table 8 Here}

To address theoretical predictions of the model, Panel A organizes the data by the year in which foreclosure occurred and Panel B organizes the data by the year in which asset sale occurred. Column (2) provides a comparison of the transfer value with the loan balance at the time of foreclosure. This comparison as shown in Panel A provides insight into the borrower's first-stage 
default decision. Given that the shocks to B and W were generally most severe near the beginning of the sample period, in which the market conditions continued to deteriorate for several years and then gradually recovery (see Figure 3), there is a clear negative correlation between wealth levels and the transfer value-loan balance ratio. This relation suggests that, when the shock was large and market conditions were deteriorating, borrowers willingly defaulted with the expectation that foreclosure might occur. This in turn suggests that continuation values were negative, even at relatively high current value-to-loan balance ratios. In comparison, ratios are much lower when the recovery had begun (W's were higher and increasing), indicating that assets had to be especially hard hit (large B's were realized) in order for an option-based default to occur.

To begin to estimate firesale discounts, in column (3) we display the ratio of the asset sale price to the transfer value. This measure is relatively crude, without the cost and market adjustments discussed above. Nonetheless, the data are informative and indicate that sales prices were approximately 25 percent less than the transfer value on average over the entire sample period, and that discounts decrease as a function of wealth levels at the time of foreclosure (Panel A).

In Column (4) we adjust the transfer value by adding in the present value of capital expenditures incurred by the lender over the asset holding period. The idea here is that the transfer value was estimated prior to capital expenditures, whereas the sales price increased as a result of the investments. To obtain a present value, we discount annual expenditures incurred over the holding period at 10 percent to the date at which the asset is transferred to inventory. ${ }^{21}$ Inclusion of capital expenditures in the denominator of the sale price-acquisition value ratio increase the estimated firesale discount to 30 percent on average.

A fully adjusted estimate of the firesale discount is provided in column (5). Using NCREIF property index data, we adjust individual sales prices to account for market-wide changes in asset prices that were realized over the inventory holding period. Once this adjustment is made, timing differences before the foreclosure and asset sale dates are fully addressed. Because market-wide asset values generally declined over the various holding periods, an upward adjustment in the asset sales price tends to occur to decrease the estimated firesale discount. With this final adjustment, the data suggest that distressed commercial real estate assets that were subsequently repossessed by the lender were sold at a 20 percent discount to their fundamental values on average. ${ }^{22}$

\footnotetext{
${ }^{21}$ Measured returns to privately held commercial real estate assets are typically in the 8-10 percent range.

22 There are other possible adjustments that might be made. For example, we presume that realized market value adjustments are in line with market value changes expected by the lender at the time of foreclosure. We suspect that expected value changes exceeded realized changes for most of the sample period. We also do not attempt account for the positive NPV increment associated with capital expenditures, implicitly assuming that cost equals value. These adjustments
} 
As predicted by the model, the size of the estimated discount is seen to vary systematically as a function of market conditions at the time of foreclosure (Panel A). Discounts of roughly 30-35 percent were realized towards the beginning of the market downturn. Discounts then declined to the 20 percent range during the middle years of the sample period, as the downturn wore on and the market began to recover. Finally, firesale discounts effectively disappeared in 1994 and 1995, years in which significant liquidity returned to the market. Also observe that the time-to-asset sale varies directly with the cycle, with longer (shorter) holding periods associated with worse (better) market conditions.

Thus, based on the year of foreclosure, there is a clear negative relation between sector liquidity and the magnitude of the firesale discount. This relationship is much less clear when the data are organized by year of asset sale (see Panel B). This outcome is again predicted by the model, where the endogeneity of the asset sale decision smoothes time variation in the firesale discount estimate. The endogenous timing effect can also be seen in the time-to-asset sale data, which are also smoothed.

\section{Regression Analysis}

In this section we use detailed loan data on restructuring-foreclosure decisions as well as on foreclosed asset sale outcomes to formally assess the model's comparative static predictions. Because the logical structure of the model is based on backward induction, we present the stage-3 (foreclosed asset sale timing) model specification and results first, and then follow with an analysis of stage- 2 (restructuring versus foreclosure decision) outcomes.

\subsection{The Timing Decision to Sell a Foreclosed Asset}

Data on foreclosed asset sales allow for tests of predictions of the third stage of the model. To do this we specify a proportional hazards model of the time to asset sale. Using foreclosure data from assets that sold during the 1986-95 time period, the hazard model provides estimates of the probability of an asset sale in a particular quarter, conditional on a sale not yet having occurred. The probabilities implied in the coefficient estimates (a positive coefficient implies a higher probability of sale relative to the baseline) thus provide a method to assess model predictions. Cross-sectional and time varying proxies for sector wealth, as well as variables that control for other factors that may influence the time required to sell an asset, are explanatory variables in the hazard model.

would increase the magnitude of the estimated firesale discount. In the other direction, we ignore total asset depreciation realized over the holding period, and focus only on capital expenditures. Our judgement is the net effect of these omitted adjustments is likely to be small. 
The model predicts that the lender takes longer to sell a foreclosed asset when sector wealth, $\mathrm{W}$, is low. Specifically, the model suggests foreclosed assets are sold quickly when W is above a critical value at the time of default, whereas asset sale is delayed until $\mathrm{W}$ increases when $\mathrm{W}$ is below the critical value. To proxy for sector wealth, we begin by assuming that the natural buyers of distressed commercial real estate-the the most efficient managers (those with the lowest $\beta_{2}$ values)-are existing commercial real estate owner-managers. These entities are likely to have experience owning and managing property types similar to those they are interested in buying. Property type thus proxies for cross-sectional variation in sector wealth, in the sense that higher-shock sectors are predicted to experience longer times to asset sale.

REIT prices are a natural time-varying proxy for the wealth of commercial real estate managers (see section 3.2 and Figure 3). REITs were used in the early to middle 1990s by seasoned real estate professionals as a vehicle to access capital and purchase discounted assets; consequently, access to liquidity was capitalized into REIT prices during that time. Higher REIT prices indicate greater wealth available to natural real estate buyers, and therefore are predicted to cause faster times to sale.

We also include variables that measure the management specificity of the foreclosed asset, since there are fewer skilled managers available to manage complex assets. That is, the market is thinner for management-specific assets, implying that it should take longer to match buyers and sellers regardless of the level of potential buyer wealth. Hotel property is considered to be more management intensive than the other property types included in the sample, and therefore is predicted to take a longer time to sell. Estimated asset value at the time of foreclosure (the asset's transfer value) is also a proxy for management specificity, in that larger assets typically require greater management expertise. Larger assets also require more capital for acquisition purposes. Consequently, larger assets are hypothesized to result in a slower rate of asset sale.

Three control variables are also included in the model specification. A bankruptcy dummy variable indicates whether the foreclosed asset was included part of a broader bankruptcy action. A package sale dummy variable indicates whether the asset was bundled together with other assets as part of a bulk sale. Finally, a purchase money dummy variable indicates whether the lender provided debt financing as part of the asset sale.

Estimation results are reported in Table 9. The REIT price coefficient is positive and highly significant: greater (lesser) sector wealth reduces (increases) time-to-sale. Relative to office property, the omitted category, apartments experience a shorter time in inventory. This is as expected since the apartment property sector experienced the mildest shock to fundamentals, implying that there were a greater number of well capitalized potential buyers available. Neither the hotel nor transfer value 
coefficients are statistically significant. The hotel property finding may have been influenced by the slightly less severe shock in the hotel sector relative to office property, which has the offsetting effect of reducing time in inventory.

\section{Table 9 Here}

The bankruptcy dummy variable coefficient is positive and statistically significant, indicating faster times to sale than the baseline. We believe this result follows from two possible effects: (1) bankruptcies often involve borrower issues other than those specific to the foreclosed asset, implying that sample assets that are part of a bankruptcy proceeding might be of higher quality than average and hence easier to sell, and (2) bankruptcy causes delays in the ability to foreclose, implying that bankrupt assets arrive later in the cycle with significant delays already realized, with a lender that is eager to sell quickly. The package sale dummy variable coefficient is negative and weakly significant, indicating slower times to sale. Package deals often contain assets of lower quality, suggesting longer times to sale. Package sales are also often complex to execute and evaluate, and harder to negotiate. The purchase money variable coefficient is insignificant. $^{23}$

In sum, the hazard model results are broadly consistent with third stage model predictions. Specifically, these results: (1) suggest that asset sale timing varied as a function of sector wealth in ways predicted by the model, and (2) complement the findings of Pulvino (1998) and Brown (2000), who examine the transacted prices of distressed assets.

\subsection{The Decision to Restructure versus Foreclose a Distressed Loan}

Model implications are now examined in the context of whether a defaulted loan is restructured or foreclosed. Recall that the lender's restructuring versus foreclosure decision hinges on the tradeoff between correcting financing distortions through a costly loan write-down versus foreclosing and selling the asset to a more liquid but possibly less efficient outside investor. Model structure predicts that default resolution depends importantly on the magnitude of the shock to project fundamentals, B, the extent of asset management specificity, $\beta_{2}-\beta_{1}$, and wealth levels of outside buyers, $\mathrm{W}$.

As shown in Figure 2, when B is smaller, borrowers tend to default strategically in anticipation of a loan restructuring. When B is larger, borrowers tend to default because their continuation value is negative, implying a relatively high proportion of foreclosure outcomes. Thus, the proportion of loans

\footnotetext{
${ }^{23}$ Our main results are robust, in the sense that inclusion of these three control variables does not affect the signs or statistical significance of the other variables included in the model specification.
} 
that are restructured versus foreclosed depends on the distribution of B across the sample of financially distressed borrowers, where the model predicts that a larger proportion of defaulted loans are restructured (foreclosed) when the sample of borrowers experiences milder (more severe) B shocks.

Higher industry wealth, W, makes foreclosure more attractive to the lender. However, B and W are highly correlated in the data. That is, we focus on an industry that experienced a significant economic downturn that sidelined many experienced industry insiders. This correlation makes it more difficult to isolate B effects separately from $\mathrm{W}$ effects, as well as biases coefficient estimates towards zero.

The lender's inventory of foreclosed assets is a compelling proxy for potential buyer wealth as distinct from the asset-level shock, B. Model predictions and previous evidence indicate that when the lender holds a large inventory of foreclosed assets, the market for distressed assets is weak. Thus, higher relative levels of asset inventory imply lower industry wealth and therefore an increased propensity to restructure.

Property type is used to proxy for variation in the depth of the project value shock, since, as seen in Table 1, the link between asset value and property type is direct. Apartment property is a lowshock sector in relation to other property types, which, after accounting for the effect of endogenous borrower default, predicts a higher likelihood of restructuring.

REIT prices proxy for the wealth levels of potential buyers, as distinct from project value shock effects. As noted earlier, growth opportunities associated with the purchase of discounted assets-i.e., access to liquidity — were capitalized into REIT asset prices during the sample period. Higher REIT prices thus imply greater sector wealth, which in turn is predicted to increase the likelihood of foreclosure.

The model also predicts that assets that are more management specific $\left(\beta_{1}<<\beta_{2}\right)$ are less likely to be foreclosed. As noted earlier, larger assets and hotel properties are more complex and manager specific. Thus, we expect the probability of foreclosure to be negatively related to initial loan size and the hotel property indicator variable.

A number of control variables are included in this specification. The loan-to-value ratio, debt service coverage ratio, and loan term at the time of issuance are included to control for differences in contracting and financial structure. Loan age at the time of default is included to control for seasoning that effects the equity position in the asset. We also have information as to the borrower type, where the categories include individual, partnership and other. We indicate whether the loan was domiciled in a judicial foreclosure or a power-of-sale state, where judicial foreclosure is typically a more time consuming process. In a small number of cases, a second mortgage was used to finance the project (the 
second mortgage is junior to the first mortgage held by the lender). Finally, we include the bankruptcy indicator variable discussed previously.

The lender's propensity to foreclose versus restructure a defaulted commercial real estate loan is estimated with a logit model, with results reported in Table 10. The model is estimated based on the sample of 631 financially distressed loans, in which the independent variable takes on a value of one if the loan was foreclosed (342 observations) and zero if the loan was reorganized (289 observations).

\section{Table 10 Here}

The coefficient on the beginning-period inventory variable is negative and significantly different from zero at the $1 \%$ level. The lender is more willing to restructure a distressed loan when the market for foreclosed property is weak, as evidenced by a large beginning-period inventory of foreclosed property. This also implies that the lender took into consideration the expected payoffs from carrying an asset in inventory when making its decision to restructure versus foreclose a defaulted loan.

The coefficient on the apartment property dummy variable is negative and statistically significant. The combined result that (1) a small proportion of apartment loans were foreclosed when the shock to the apartment sector was smaller and (2) foreclosed apartment properties were readily sold out of inventory is consistent with the idea that few apartment property owners found the value shock to be large enough to default when they anticipated that the lender would foreclose. Instead, the defaults that did occur were likely to be strategic, i.e. in anticipation of restructuring.

The REIT price variable (a proxy for time-varying wealth effects) is positive and significant. These results are consistent with model predictions in the sense that a higher-B/higher-W combination is predicted to result in a foreclosure, whereas a lower- $\mathrm{B} /$ lower-W combination is predicted to result in

a restructuring (see Figure 2). These results are unlikely to be explained by the models of Stromberg (2000) and Habib and Johnsen (1999), which predict that defaulted loans are more likely to be liquidated because the incumbent managers are less capable.

The Hotel and Loan Size variables proxy for asset management specificity. The coefficients on both variables are negative and statistically significant. This supports the contention that incumbent owner-managers are generally more skilled than outside investors at operating the asset, and therefore that the investment distortion-outsider wealth tradeoff is relevant to the lender when considering whether to restructure or foreclose a loan. 
Of the control variables, only the judicial state dummy and the second mortgage dummy variable coefficients are statistically significant. The positive coefficient on the judicial dummy indicates a propensity to choose foreclosure over workout. This result is somewhat puzzling, since one would infer that a more bureaucratic foreclosure process might be more costly, causing the lender to prefer workout over foreclosure. It might be that this expected cost is priced at the time of debt issuance, causing an additional financial burden and therefore increasing the borrower's willingness to walk away from the investment. The second mortgage dummy has a weakly significant negative coefficient, suggesting that a more complex capital structure leads to a preference for restructuring. This is consistent with Gilson et al. (1990), who find that liquidations are less frequent when the firm's preexisting capital structure is more complicated. ${ }^{24}$

In summary, the logit model estimation results support predictions of the model developed in this paper. Specifically, the data suggest that: (1) default decisions by the borrower are endogenous and depend importantly on the size of the shock to project fundamentals, and (2) the lender considered the wealth and relative management skills of potential buyers in the restructuring-foreclosure decision.

\section{Conclusion}

This paper provides a model of a financially distressed owner-managed project. Several key elements drive the model. First, a project-level shock is realized to cause financial distress and a debt overhang problem. The need to restore proper investment incentives forces the lender to either forgive some debt through a restructuring or foreclose. Restructuring is more attractive when significant goingconcern value exists due to the relative productivity of the incumbent owner-manager and when the pool of buyers for the foreclosed asset is thin and wealth constrained. Because the lender cannot capture a large part of the gains from a restructuring, foreclosure is increasingly preferred as the wealth and efficiency of outside buyers increase. These features explain the co-existence of restructuring and liquidation in the data, and why transparent and simply capitalized owner-managed firms are frequently liquidated in financial distress.

If the borrower anticipates that default will lead to debt forgiveness, a strategic default occurs. If the borrower anticipates that the defaulted loan will be foreclosed, default only occurs when the project's continuation value (equity position) is worth less than the cost of keeping the loan current. Thus, the size of the shock to project value and the market for foreclosed assets interact to determine whether the borrower defaults as well as the outcome of default.

\footnotetext{
${ }^{24}$ As with stage- 3 estimation results, the crucial relationships in this section that involve $\mathrm{B}, \mathrm{W}$, and $\beta$ are robust to the exclusion of the control variables.
} 
Asset value is endogenous in our model because owner-manager investment is endogenous and because industry market conditions vary to affect the realized sales price of foreclosed assets. Our approach thus references and extends Titman et al. (2001), who, in an owner-managed project setting, focus on underinvestment with non-discretionary liquidation as an explanation for endogenous asset values and borrower default decisions.

Our approach complements and extends Shleifer and Vishny's (1992) model of firm-level financial distress when the entire industry experiences liquidity problems. In their model incumbent managers are efficient, but have incentives to overinvest due to a leveraged financial structure and an adverse shock to asset values. The borrower defaults and the lender liquidates and subsequently sells at firesale prices to less productive outside investors. The magnitude of the firesale discount thus depends on the depth of the industry-wide economic shock. Our owner-manager model considers underinvestment rather than overinvestment distortions, but otherwise captures and then extends all of the salient aspects of the Shleifer-Vishny approach. In our model borrower default is endogenous, the lender has discretion to restructure or liquidate, and the lender chooses when to sell foreclosed assets to outside investors. This additional structure provides additional insight into the causes and consequences of financial distress as well as the lender's role in liquidity provision in the market for distressed real assets.

A unique prediction of our model is that, although the lender might unconditionally prefer to restructure (foreclose) when market conditions are deteriorating (improving), endogenous borrower default can reverse the realized outcomes. This reversed pattern of restructuring-foreclosure outcomes is observed in a unique data set of financially distressed commercial real estate mortgages. The data correspond to a severe downturn and subsequent recovery in commercial real estate experienced in the 1980s and 1990s. Detailed data exist on the lender's restructuring-foreclosure decision as well as the lender's foreclosed asset sale timing decision. We also have observations on default realizations by year of loan origination and year of onset of financial distress. The data support many of the predictions of the model, including the existence of endogenous borrower default, significant underinvestment in foreclosed assets, liquidity provision alá delayed asset sales in response to weak industry conditions, and firesale discounts that vary depending on market conditions at the time of foreclosure. 


\section{Appendix}

This appendix begins with an analysis of the second and first stages of the game when the distressed borrower (the incumbent owner-manager) has personal wealth greater than zero to invest in the project, i.e. the general case. The incumbent's personal wealth is denoted $\mathrm{W}_{\mathrm{I}}$ and the presumption of limited liability (non-recourse) is retained. Proofs of Propositions 1 and 3 are provided for the general case (stages 2 and 1 of the financial distress game, respectively). A proof of Proposition 2 is provided as it relates to stage 3 of the financial distress game.

\section{Proof of Proposition 1 (the restructuring-foreclosure decision) in the General Case}

In this setting, we suppose that, conditional on default, the lender holds an auction for the asset. The distressed incumbent owner-manager can obtain outside financing from another lender or renegotiate with the existing lender. In either case, the maximum amount that the distressed borrower is willing to pay for the asset follows directly from equations (4) and (5). Specifically, the incumbent manager is willing to pay up to $\mathrm{W}_{\mathrm{I}}+(\mathrm{V}-\mathrm{B})^{2} / 8 \beta_{1}$ for the asset assuming the participation constraint is binding. Thus, the condition necessary for the asset to be sold to an outsider is

$$
\mathrm{W}+(\mathrm{V}-\mathrm{B})^{2} / 8 \beta_{2}>\mathrm{W}_{\mathrm{I}}+(\mathrm{V}-\mathrm{B})^{2} / 8 \beta_{1}
$$

This result is very similar to equation (6) and, assuming the participation constraint is satisfied for the incumbent (i.e. equation (7)), the condition under which an outside buyer is willing to pay more for the asset than the lender's payoff in a restructuring is

$$
\mathrm{W} \geq \underline{\mathrm{W}}=\operatorname{Max}\left\{\mathrm{W}_{\mathrm{I}}+\left(\frac{(\mathrm{V}-\mathrm{B})^{2}}{8}\right)\left[\frac{1}{\beta_{1}}-\frac{1}{\beta_{2}}\right], 0\right\}
$$

Thus, in the general model foreclosure occurs when condition (A.2) holds. That is, foreclosure occurs when the difference between the potential buyer's wealth and the distressed owner-manager's wealth is sufficiently large so as to overcome the relative inefficiency of the outside manager. Observe that in this more general case it is possible for an inefficient but well endowed incumbent to outbid a more efficient but relatively wealth constrained outside buyer.

It is important to note that when the distressed owner-manager has wealth, she may be required to contribute some wealth in a restructuring to win the auction. In other words, $\mathrm{W}_{\mathrm{I}}$ is endogenous in 
the sense that the distressed owner-manager may vary her equity contribution depending on competitive industry conditions. In particular, if (A.2) does not hold, the distressed borrower must contribute $\mathrm{W}^{*}$ in a restructuring to win the auction where

$$
\mathrm{W}^{*}=\operatorname{Max}\left\{0,(\mathrm{~V}-\mathrm{B})^{2} / 8 \beta_{1}-\mathrm{W}-(\mathrm{V}-\mathrm{B})^{2} / \beta_{2}\right\}
$$

The major implications of this general case as compared to the $\mathrm{W}_{\mathrm{I}}=0$ case considered in the body of the text are that: (1) restructurings are more likely, and (2) the lender captures a greater share of the rents in a restructuring.

\section{Proof of Proposition 3 (the borrower's default decision) in the General Case}

The following demonstrates the conditions under which the borrower chooses to default. The borrower defaults when the payoff from continuation is less than the payoff in default. The borrower's payoff from continuation is

$$
\rho\left(P_{1}\right)\left[V-B-P_{1}\right]-P_{0}-C\left(\rho\left(P_{1}\right)\right)
$$

If the borrower defaults the lender can either foreclose, which results in a zero payoff to the borrower, or restructure. The borrower anticipates that foreclosure will occur when equation (A.2) is satisfied. Thus, the borrower defaults when foreclosure is anticipated for all B greater than B* where

$$
\rho\left(\mathrm{P}_{1}\right)\left[\mathrm{V}-\mathrm{B}^{*}-\mathrm{P}_{1}\right]-\mathrm{P}_{0}-\mathrm{C}\left(\rho\left(\mathrm{P}_{1}\right)=0\right.
$$

Solving equation (A.5) for B* results in the condition for default when foreclosure is anticipated, as indicated in Proposition 3.

Now consider the case when $\mathrm{W}_{\mathrm{I}}>0$, i.e., when the borrower has wealth to contribute to a restructuring. To begin, observe that the condition presented in Proposition 3 does not depend on the level of incumbent wealth, because neither the owner-manager's payoff in continuation or foreclosure depend on $\mathrm{W}_{\mathrm{I}}$. However, payoffs from a restructuring do depend on $\mathrm{W}_{\mathrm{I}}$ and $\mathrm{W}$. In the case presented in the text, where $\mathrm{W}_{\mathrm{I}}=0$, the debt is restructured to a level $\mathrm{F}_{1}{ }^{*}$. Since, $\mathrm{F}_{1}{ }^{*}$ is less than $\mathrm{P}_{1}$, it is always the case that the borrower defaults when the borrower anticipates a restructuring.

In the case where $\mathrm{W}_{\mathrm{I}}$ is positive, the payoffs in a restructuring maybe reduced because the distressed borrower must contribute some funds, as shown in (A.3). Thus, the borrower does not 
default for all realizations of B. The shock must be sufficiently large so that a restructuring dominates continuation. However, a smaller shock is required to trigger default when restructuring is anticipated than when foreclosure is anticipated. The shock to trigger default followed by restructuring is smaller than $\mathrm{B}^{*}$ as stated in Proposition 3 because the borrower payoffs are greater than zero in a restructuring.

\section{Proof of Proposition 2 (analysis of foreclosure with delayed sale)}

First, we wish to show that $\breve{\mathrm{W}}<\widetilde{\mathrm{W}}$. Recall that $\widetilde{\mathrm{W}}$ is the value of $\mathrm{W}$ such that $\mathrm{W}_{\mathrm{t}+1}-\mathrm{K}=\mathrm{W}$ and that $\breve{\mathrm{W}}$ is the value of $\mathrm{W}$ such that $\mathrm{W}_{\mathrm{t}+1}-\mathrm{K}=\underline{\mathrm{W}}$. Given assumptions (1)-(3), because $\mathrm{W}$ is less than $\underline{\mathrm{W}}$ at $\mathrm{W}_{\mathrm{t}+1}-\mathrm{K}=\underline{\mathrm{W}}$, it must be that $\breve{\mathrm{W}}<\widetilde{\mathrm{W}}$. Furthermore, $\mathrm{W}$ less than $\breve{\mathrm{W}}$ implies that $\mathrm{W}_{\mathrm{t}+1}-\mathrm{K}$ $<\underline{\mathrm{W}}$, which all together establishes the existence of the three regions claimed in the proposition.

The Figure below displays outcomes for the three cases discussed in the section. Case A corresponds to $\widetilde{\mathrm{W}}<\underline{\mathrm{W}}$ (foreclosure-delayed sale never occurs), case $\mathrm{B}$ corresponds to $\mathrm{W}_{\mathrm{t}+1}-\mathrm{K}>\underline{\mathrm{W}}$ for all W (restructuring never occurs), and case $\mathrm{C}$ is the intermediate case presented in proposition 3 in which all three outcomes (restructuring, foreclosure-delayed sale, foreclosure-immediate sale) are possible. The heavy line arrows indicate different restructuring-foreclosure outcome regions as a function of $\mathrm{W}$ in case $\mathrm{C}$.

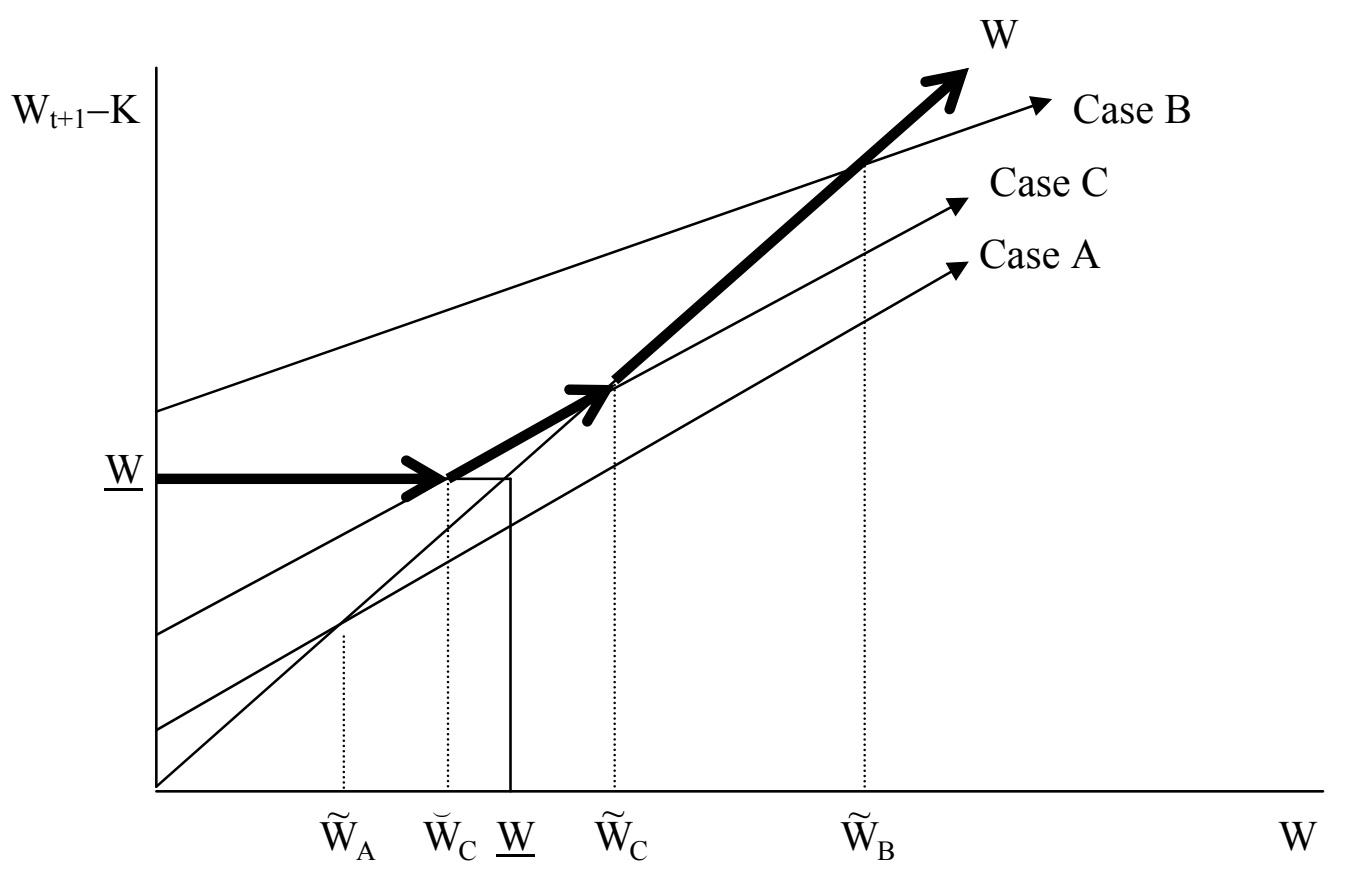


More specifically, as displayed in the Figure, outcomes for the three cases as a function of $\mathrm{W}$ are as follows:

Case A: $\mathrm{W}<\widetilde{\mathrm{W}}_{\mathrm{A}}$, restructure; $\mathrm{W}>\widetilde{\mathrm{W}}_{\mathrm{A}}$, foreclose-immediate sale.

Case B: $\mathrm{W}<\widetilde{\mathrm{W}}_{\mathrm{B}}$, foreclose-delayed sale; $\mathrm{W}>\widetilde{\mathrm{W}}_{\mathrm{B}}$, foreclose-immediate sale.

Case C: $\mathrm{W}<\breve{\mathrm{W}}_{\mathrm{C}}$, restructure; $\breve{\mathrm{W}}_{\mathrm{C}}<\mathrm{W}<\widetilde{\mathrm{W}}_{\mathrm{C}}$, foreclose-delayed sale, $\mathrm{W}>\widetilde{\mathrm{W}}_{\mathrm{C}}$, forecloseimmediate sale. 


\section{References}

Acharya, Viral V. and Jennifer N. Carpenter, 2002, "Corporate Bond Valuation with Stochastic Interest Rates and Endogenous Bankruptcy," Review of Financial Studies 15, 1355-1383.

Anderson, Ron, and Suresh M. Sundaresan, 1996, "Design and Valuation of Debt Contracts," Review of Financial Studies 9, 37-68.

Asquith, Paul, Robert Gertner, and David Scharfstein, 1994, "Anatomy of Financial Distress: An Examination of Junk Bond Issuers,” Quarterly Journal of Economics 109, 635-658.

Baird, Douglas G. and Thomas H. Jackson, 1988, "Bargaining After the Fall and the Contours of the Absolute Priority Rule," University of Chicago Law Review 55, 738-789.

Black, Fisher, and Myron Scholes, 1973, "The Pricing of Option Contracts and Corporate Liabilities," Journal of Political Economy 81, 637-654.

Brown, David, 2000, "Liquidity and Liquidation: Evidence from Real Estate Investment Trusts," Journal of Finance 55, 469-485.

Bulow, J.I., and J.B. Shoven, 1978, “The Bankruptcy Decision,” Bell Journal of Economics 9, 437456.

Ciochetti, Brian A., 1997, "Loss Characteristics of Commercial Mortgages," Real Estate Finance 14 (Spring), 53-69.

Clauretie, Terrence M. and Thomas Herzog, 1990, "The Effect of State Foreclosure Laws on Loan Losses: Evidence From the Mortgage Insurance Industry," Journal of Money Credit and Banking 22, 221-233.

Dewatripont, Mathias, Patrick Legros, and Steven Matthews, 2002, "Moral Hazard and Capital Structure Dynamics,” unpublished manuscript, Penn Institute for Economic Research.

Esaki, Howard, and Masumi Goldman, 2005, "Commercial Mortgage Defaults: 30 Years of History," CMBS World 6:4, 21-29.

Fan, Hua, and Suresh M. Sundaresan, 2000, "Debt Valuation, Renegotiations and Optimal Dividend Policy, Review of Financial Studies 13, 1057-1099.

Fergus, James and John Goodman, 1994, "The 1989-1992 Credit Crunch for Real Estate: A Retrospective," Real Estate Economics 22, 5-32.

Fisher, Jeffrey D., Brent C. Smith, Jerrold J. Stern and R. Brian Webb, 2001, "Analysis of Economic Depreciation of Multi-Family Property," Unpublished Manuscript, Indiana University.

Gilson, Stuart, Kose John and Larry Lang, 1990, “Troubled Debt Restructurings: An Empirical Study of Private Reorganizations of Firms in Default," Journal of Financial Economics 26, 315-354. 
Habib, Michel and D. Bruce Johnsen, 1999, "The Financing and Redeployment of Specific Assets, Journal of Finance 54, 693-720.

Innes, Robert, 1990, "Limited liability and incentive contracting with ex-ante action choices," Journal of Economic Theory, 52: 45-67.

James, Christopher, 1995, "When Do Banks Take Equity in Debt Restructurings," Review of Financial Studies 8, 1209-1234.

Mella-Barral, P., and W.R.M. Perraudin, 1997, "Strategic Debt Service," Journal of Finance 52, 531556.

Merton, Robert, 1974, "On the Pricing of Corporate Debt: The Risk Structure of Interest Rates, Journal of Finance 29, 449-470.

Peek, Joe, and Eric Rosengren, 1994, "Bank Lending and the New England Capital Crunch," Real Estate Economics 22, 33-58.

Pulvino, Todd, 1998, "Do Asset Fire Sales Exist? An Empirical Investigation of Commercial Aircraft Transactions," Journal of Finance 53, 1343-1365.

Riddiough, Timothy J. and Steve B. Wyatt, 1994, "Wimp or Tough: Sequential Default Risk and Signaling With Mortgages,” Journal of Real Estate Finance and Economics 9, 299-321.

Schleifer, Andrei and Robert Vishny, 1992, "Liquidation Value and Debt Capacity: A Market Equilibrium Approach," Journal of Finance 47, 1343-1365.

Stromberg, Per, 2000, "Conflicts of Interest and Market Illiquidity in Bankruptcy Auctions: Theory and Tests," Journal of Finance 55, 2641-2692.

Titman, Sheridan, Stathis Tompaidis, and Sergy Tsplakov, 2001, "Market Imperfections, Investment Optionality and Default Spreads," Forthcoming, Journal of Finance.

Williams, Joesph, 2001, “Agency, Ownership and Returns on Real Assets," unpublished manuscript, Professors Capital.

Wang, Ko, Leslie Young and Yuqing Zhou, 2002, "Nondiscriminating Foreclosure and Voluntary Liquidating Costs," Review of Financial Studies 15, 959-985.

Warren, Elizabeth, 1987, “Bankruptcy Policy,” University of Chicago Law Review 54, 775-814. 


\section{Figure 1}

\section{The Stages of Financial Distress}

Figure 1 depicts the financial distress process. A negative shock of size B to project value occurs. The initial move is made by the borrower, who chooses whether to default or make the loan payment. Conditional on default, the loan is either restructured or foreclosed. Finally, the lender chooses to either manage the foreclosed asset in-house for a period of time or liquidate the project through a sale to a third party.

Negative Shock

To Project

Value Occurs
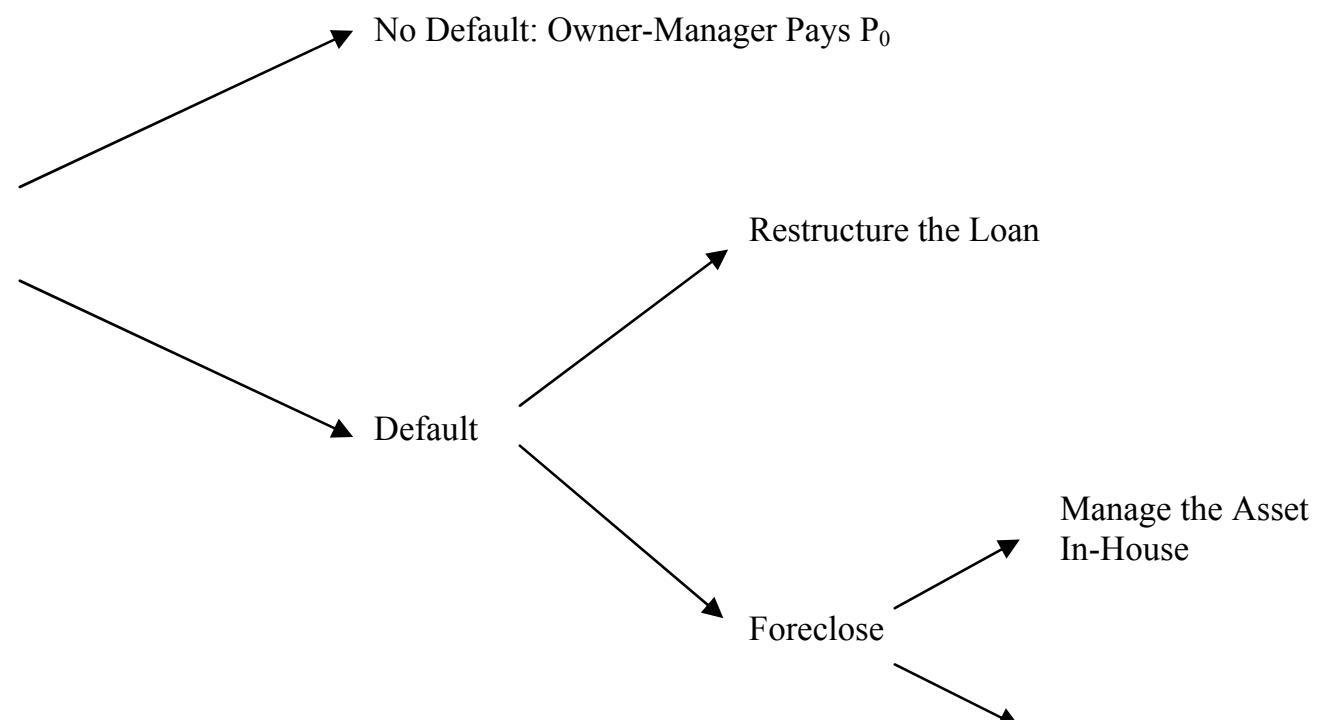

Sell the Asset to an Outside Investor 
Figure 2

The Equilibrium Default-Restructuring-Foreclosure Decision in (B,W) Space

Figure 2 depicts realizations of $\mathrm{B}$ (the size of the shock to project value) and $\mathrm{W}$ (the wealth of potential buyers) that result in (a) continuation (no default), (b) restructuring, (c) foreclosure and immediate asset sale, and (d) foreclosure and delayed asset sale. When $\mathrm{W}>\breve{\mathrm{W}}$ and $\mathrm{B}<\mathrm{B}^{*}$, the borrower continues (does not default), since foreclosure is a credible option for the lender and the expected payoff to continuation is positive. When $\mathrm{W}<\breve{\mathrm{W}}$, the borrower defaults and the loan is restructured. In this case, if $\mathrm{B}<\mathrm{B}^{*}$, the borrower defaults strategically knowing the lender will restructure. If $\mathrm{B}>\mathrm{B}^{*}$ and $\mathrm{W}$ $>\breve{\mathrm{W}}$, the borrower defaults anticipating foreclosure, since continuation has a negative value. When $\breve{W}<W<\widetilde{W}$ and $B>$ $\mathrm{B}^{*}$, the borrower defaults, the loan is foreclosed and asset sale is delayed. When $\mathrm{W}>\widetilde{\mathrm{W}}$ and $\mathrm{B}>\mathrm{B}^{*}$, the borrower defaults, the loan is foreclosed and asset sale is immediate.

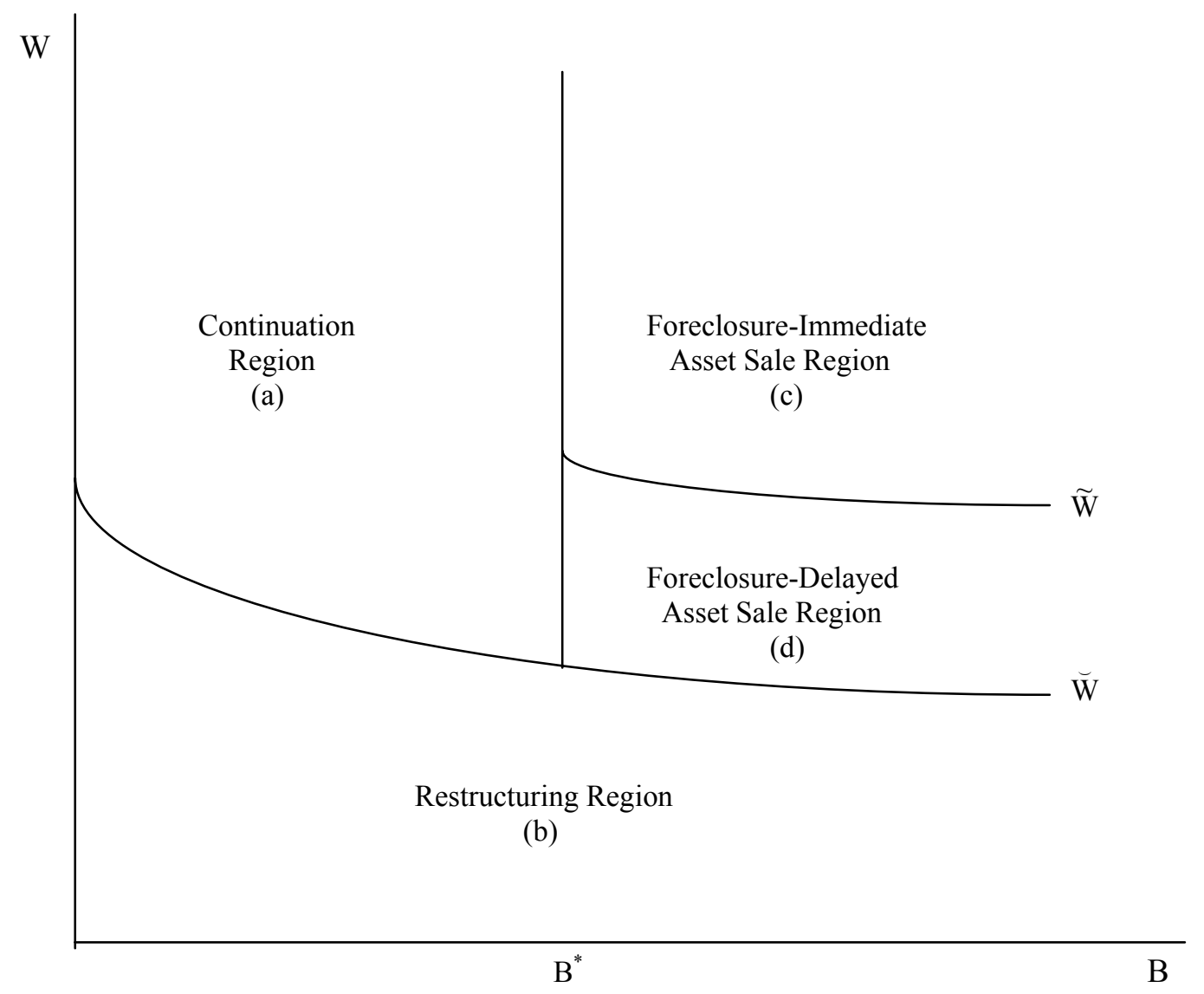


Figure 3

\section{Commercial Real Estate Values and Cash Flows as Measured by the NAREIT Equity Index}

Figure 3 traces the value of a $\$ 100$ position invested in the National Association of Real Estate Investment Trusts (NAREIT) Equity REIT Index and the NAREIT Rent Index from 1982 through 1996. The NAREIT Rent Index is the product of the NAREIT Equity Index and the dividend yield on that index.

REIT Price Index

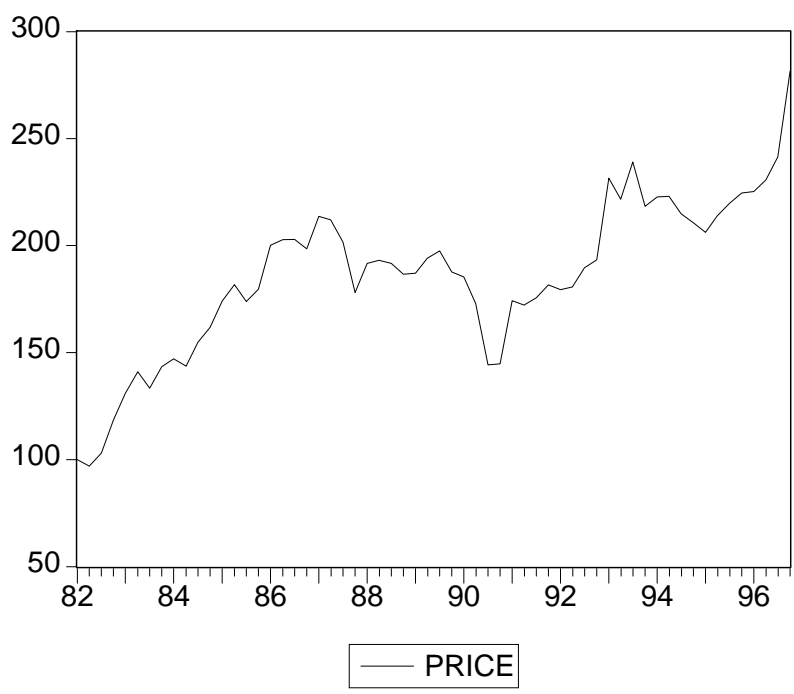

REIT Rent Index

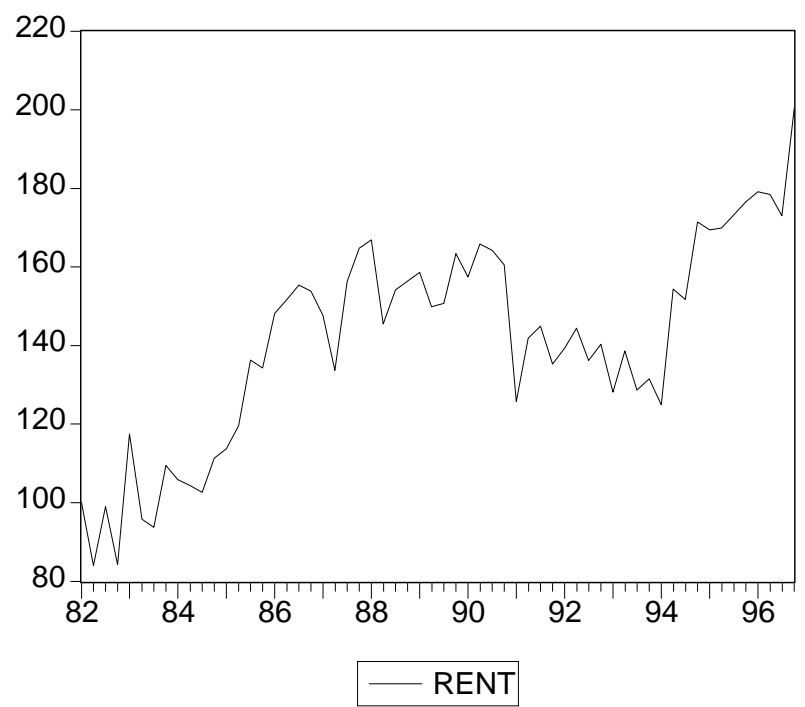


Table 1

\section{Commercial Real Estate Asset Value Declines by Property Segment}

Table 1 shows the percent decline in asset values from the peak of the property cycle prior to the real estate downturn through the trough of the cycle for four core property types: Apartment, Office, Retail, and Industrial. Asset value changes are calculated using NCREIF index data.

\begin{tabular}{|c|c|}
\hline Property Segment & Asset Value Decline \\
\hline Apartment & $-16.8 \%$ \\
\hline Office & $-53.2 \%$ \\
\hline Retail & $-20.2 \%$ \\
\hline Industrial & $-30.2 \%$ \\
\hline
\end{tabular}


Table 2

Financially Distressed Loans by Property Type and Loan Size

Table 2 categorizes the number of restructured and foreclosed loans by property type and initial loan size. Percentages are by loan size category for each property type.

\begin{tabular}{|c|c|c|c|c|c|c|c|}
\hline Loan Size & Apartment & Hotel & Industrial & Office & Retail & Other & Total \\
\hline$<\$ 2 m$ & 22 & 0 & 13 & 36 & 14 & 1 & 86 \\
& $11.5 \%$ & $0.0 \%$ & $19.4 \%$ & $13.4 \%$ & $20.6 \%$ & $10.0 \%$ & $13.6 \%$ \\
\hline $\mathbf{\$ 2 - \$ 4 m}$ & 45 & 0 & 26 & 36 & 11 & 0 & 118 \\
& $23.6 \%$ & $0.0 \%$ & $38.8 \%$ & $13.4 \%$ & $16.2 \%$ & $0.0 \%$ & $18.7 \%$ \\
\hline $\mathbf{\$ 4 - \$ 7 m}$ & 67 & 4 & 15 & 47 & 16 & 1 & 150 \\
& $35.1 \%$ & $15.4 \%$ & $22.4 \%$ & $17.5 \%$ & $23.5 \%$ & $10.0 \%$ & $23.8 \%$ \\
\hline $\mathbf{\$ 7 - \$ 1 0 m}$ & 27 & 1 & 6 & 38 & 10 & 1 & 83 \\
& $14.1 \%$ & $3.9 \%$ & $9.0 \%$ & $14.1 \%$ & $14.7 \%$ & $10.0 \%$ & $13.2 \%$ \\
\hline $\mathbf{\$ 1 0 - \$ 1 5 m}$ & 20 & 5 & 6 & 31 & 9 & 1 & 72 \\
& $10.5 \%$ & $19.2 \%$ & $9.0 \%$ & $11.5 \%$ & $13.2 \%$ & $10.0 \%$ & $11.4 \%$ \\
\hline $\mathbf{\$ 1 5 - \$ 2 5 m}$ & 7 & 11 & 0 & 39 & 3 & 1 & 61 \\
& $3.7 \%$ & $42.3 \%$ & $0.0 \%$ & $14.5 \%$ & $4.4 \%$ & $10.0 \%$ & $9.7 \%$ \\
\hline$>\$ 25 m$ & 3 & 5 & 1 & 42 & 5 & 5 & 61 \\
& $1.6 \%$ & $19.2 \%$ & $1.5 \%$ & $15.6 \%$ & $7.4 \%$ & $50.0 \%$ & $9.7 \%$ \\
\hline Total & 191 & 26 & 67 & 269 & 68 & 10 & 631 \\
& $100.0 \%$ & $100.0 \%$ & $100.0 \%$ & $100.0 \%$ & $100.0 \%$ & $100.0 \%$ & $100.0 \%$ \\
\hline
\end{tabular}


Table 3

\section{Comparison of Mortgage Loan Sample to Industry Data}

Table 3 compares the sample data to industry data . Average loan amount, average loan-to-value ratio, and average debt coverage ratio are at the time of debt issuance. We report only the five major property types, which slightly reduces the sizes of both our sample and the industry sample. Percentages are reported as a proportion of the reduced sample size, and add to 100 percent.

\begin{tabular}{ccc}
\hline & Sample & Industry \\
\hline $\mathbf{N}$ & 2,589 & 23,961 \\
Average Loan Amount & $\$ 6.78 \mathrm{~mm}$ & $\$ 7.41 \mathrm{~mm}$ \\
Average Loan-to-Value Ratio & .719 & .721 \\
Average Debt Coverage Ratio & 1.24 & 1.28 \\
& & \\
Apartment & $27.7 \%$ & $10.7 \%$ \\
Hotel & $2.4 \%$ & $8.1 \%$ \\
Industrial & $15.0 \%$ & $12.4 \%$ \\
Office & $39.1 \%$ & $48.5 \%$ \\
Retail & $15.7 \%$ & $20.3 \%$ \\
\hline
\end{tabular}


Table 4

Defaulted Loans by Year of Origination and Year of Onset of Financial Distress

Table 4 displays lifetime and annual default rates from 1986-95 for 2589 commercial mortgage loans originated by the lender. A total of 807 loans were classified as in default at some point during the sample period. The year of onset of financial distress is the year in which a loan was first reported as 90 days or more delinquent on its loan payments. Rows identify defaults by year of origination to determine a lifetime default rate. Columns identify the year in which a default occurred to provide an annual default rate. The indexed value of REIT price is shown in the bottom row, where 1985 has an index value of 100 .

Year of Onset of Financial Distress

\begin{tabular}{|c|c|c|c|c|c|c|c|c|c|c|c|c|}
\hline $\begin{array}{l}\text { Year } \\
\text { Orig. }\end{array}$ & $\begin{array}{l}\text { Number } \\
\text { Orig. }\end{array}$ & 1986 & 1987 & 1988 & 1989 & 1990 & 1991 & 1992 & 1993 & 1994 & 1995 & Total \\
\hline $1974-81$ & 1359 & 39 & 33 & 48 & 25 & 23 & 36 & 28 & 13 & 10 & 6 & $\begin{array}{c}261 \\
19.2 \%\end{array}$ \\
\hline 1982 & 68 & 13 & 0 & 1 & 1 & 0 & 0 & 0 & 1 & 0 & 0 & $\begin{array}{c}16 \\
23.5 \%\end{array}$ \\
\hline 1983 & 221 & 17 & 7 & 18 & 6 & 6 & 3 & 5 & 3 & 0 & 0 & $\begin{array}{c}65 \\
29.4 \%\end{array}$ \\
\hline 1984 & 147 & 10 & 8 & 23 & 0 & 5 & 11 & 3 & 2 & 0 & 0 & $\begin{array}{c}62 \\
42.2 \%\end{array}$ \\
\hline 1985 & 249 & 9 & 14 & 40 & 8 & 15 & 32 & 10 & 4 & 6 & 1 & $\begin{array}{c}139 \\
55.8 \%\end{array}$ \\
\hline 1986 & 188 & 2 & 14 & 12 & 7 & 18 & 24 & 13 & 6 & 2 & 0 & $\begin{array}{c}98 \\
52.1 \%\end{array}$ \\
\hline 1987 & 165 & --- & 0 & 4 & 6 & 13 & 19 & 23 & 12 & 7 & 3 & $\begin{array}{c}87 \\
52.7 \%\end{array}$ \\
\hline 1988 & 111 & --- & --- & 0 & 2 & 6 & 23 & 9 & 7 & 1 & 6 & $\begin{array}{c}54 \\
48.6 \%\end{array}$ \\
\hline 1989 & 39 & --- & --- & --- & 0 & 1 & 9 & 0 & 1 & 5 & 0 & $\begin{array}{c}16 \\
41.0 \%\end{array}$ \\
\hline 1990 & 42 & --- & --- & --- & --- & 0 & 6 & 0 & 3 & 0 & 0 & $\begin{array}{c}9 \\
21.4 \% \\
\end{array}$ \\
\hline Total & 2589 & $\begin{array}{c}90 \\
3.5 \% \\
\end{array}$ & $\begin{array}{c}76 \\
2.9 \% \\
\end{array}$ & $\begin{array}{c}146 \\
5.6 \% \\
\end{array}$ & $\begin{array}{c}55 \\
2.1 \% \\
\end{array}$ & $\begin{array}{c}87 \\
3.4 \% \\
\end{array}$ & $\begin{array}{c}163 \\
6.3 \% \\
\end{array}$ & $\begin{array}{c}91 \\
3.5 \% \\
\end{array}$ & $\begin{array}{c}52 \\
2.0 \% \\
\end{array}$ & $\begin{array}{c}31 \\
1.2 \% \\
\end{array}$ & $\begin{array}{c}16 \\
0.6 \% \\
\end{array}$ & $\begin{array}{c}807 \\
31.1 \% \\
\end{array}$ \\
\hline $\begin{array}{l}\text { REIT } \\
\text { Price }_{t}\end{array}$ & & 113.4 & 113.6 & 107.6 & 108.1 & 91.3 & 99.2 & 104.8 & 128.4 & 122.8 & 121.9 & \\
\hline
\end{tabular}




\section{Table 5}

\section{Restructured Versus Foreclosed Loans by Decision Year}

Table 5 presents the number of defaulted loans that were restructured versus foreclosed by decision year. The decision year refers to the year in which a restructuring occurred or foreclosure proceedings were initiated. The restructuring rate is the number of loans restructured in a year as a percentage of the total number of restructured and foreclosed loans in that year. We combine years 1986-88 because few loans were classified as restructured in 1986 and 1987.

\begin{tabular}{|c|c|c|c|}
\hline Decision Year & $\begin{array}{c}\text { Number of } \\
\text { Restructured Loans }\end{array}$ & $\begin{array}{c}\text { Number of } \\
\text { Foreclosed Loans }\end{array}$ & Restructuring Rate \\
\hline $1986-88$ & 90 & 148 & $37.3 \%$ \\
\hline 1989 & 19 & 29 & $39.6 \%$ \\
\hline 1990 & 25 & 43 & $36.8 \%$ \\
\hline 1991 & 73 & 59 & $55.3 \%$ \\
\hline 1992 & 35 & 32 & $52.2 \%$ \\
\hline 1993 & 32 & 18 & $64.0 \%$ \\
\hline 1994 & 14 & 9 & $60.9 \%$ \\
\hline 1995 & 1 & 4 & $20.0 \%$ \\
\hline & & & \\
\hline Total & 289 & 342 & $45.8 \%$ \\
\hline
\end{tabular}


Table 6

Foreclosures and the Propensity to Sell Assets Out of Inventory

Table 6 documents foreclosure and sales activity on foreclosed assets over the 1986-95 sample period. Specifically, the table shows: (1) the number of loans that were foreclosed during the year, (2) the number of repossessed properties sold during the year, (3) the number of properties obtained through foreclosure that remained in inventory at the end of the year, (4) the average number of months between the foreclosure date and the property sale date, and (5) the propensity of the lender to sell assets, as measured by the number of properties sold in a year as a percentage of the inventory of foreclosed properties at the prior year-end.

\begin{tabular}{|c|c|c|c|c|c|}
\hline Year & $\begin{array}{c}\text { Number of } \\
\text { Foreclosed } \\
\text { Loans } \\
\mathbf{( 1 )}\end{array}$ & $\begin{array}{c}\text { Number of } \\
\text { Properties Sold } \\
\mathbf{( 2 )}\end{array}$ & $\begin{array}{c}\text { End of Year } \\
\text { Inventory } \\
\mathbf{( 3 )}\end{array}$ & $\begin{array}{c}\text { Average } \\
\text { Ownership } \\
\text { Period } \\
\mathbf{( 4 )}\end{array}$ & $\begin{array}{c}\text { Propensity to } \\
\text { Sell Foreclosed } \\
\text { Real Estate } \\
\mathbf{( 5 )}\end{array}$ \\
\hline 1986 & 36 & 0 & 36 & n.a. & n.a \\
\hline 1987 & 45 & 2 & 79 & 7.9 & $5.6 \%$ \\
\hline 1988 & 32 & 4 & 107 & 17.1 & $5.1 \%$ \\
\hline 1989 & 46 & 27 & 126 & 27.3 & $25.2 \%$ \\
\hline 1990 & 41 & 17 & 150 & 30.3 & $13.5 \%$ \\
\hline 1991 & 70 & 19 & 201 & 21.3 & $12.7 \%$ \\
\hline 1992 & 71 & 24 & 248 & 19.6 & $11.9 \%$ \\
\hline 1993 & 41 & 79 & 210 & 31.3 & $31.9 \%$ \\
\hline 1994 & 24 & 85 & 149 & 27.4 & $40.5 \%$ \\
\hline 1995 & 6 & 13 & 142 & 26.5 & $8.7 \%$ \\
\hline & & & & & 27.3 \\
\hline Total & 412 & 270 & & & $18.7 \%$ \\
\hline & & & & & \\
\hline
\end{tabular}


Table 7

\section{Lender Capital Expenditures on Foreclosed Property}

Table 7 presents capital expenditures made by the lender on 269 repossessed assets that were later sold (one observation was excluded due to missing data) during the inventory ownership period as a percentage of the asset sale price. We also calculate the average length of the equity ownership period in months as well as annualized capital expenditures, defined as the total average capital expenditure percentage divided by the average ownership period. Data are reported for the entire sample as well as six property type categories, seven original loan size categories, and two foreclosure-year periods. The negative capital expenditure reported in the Other property type category is due to a sizable capital expenditure reserve that accompanied a foreclosed property, which proved to be more than sufficient to fund actual capital expenditures during the asset ownership period.

\begin{tabular}{|l|c|c|c|c|}
\hline \multicolumn{1}{|c|}{ Property Type } & Sample Size & $\begin{array}{c}\text { Total CapX as a \% } \\
\text { of Asset Sales Price }\end{array}$ & $\begin{array}{c}\text { Ownership Period } \\
\text { (Months) }\end{array}$ & $\begin{array}{c}\text { Annual CapX as a \% } \\
\text { of Asset Sales Price }\end{array}$ \\
\hline Apartment & 61 & $7.1 \%$ & 22.1 & $3.9 \%$ \\
\hline Hotel & 12 & $14.4 \%$ & 33.5 & $5.2 \%$ \\
\hline Industrial & 30 & $11.5 \%$ & 23.9 & $5.8 \%$ \\
\hline Office & 124 & $19.6 \%$ & 30.2 & $7.8 \%$ \\
\hline Retail & 38 & $11.8 \%$ & 27.3 & $5.2 \%$ \\
\hline Other & 4 & $-1.7 \%$ & 19.0 & $-1.1 \%$ \\
\hline Total & 269 & $14.2 \%$ & 27.3 & $6.2 \%$ \\
\hline Loan Size & & & & \\
\hline$<\$ 2$ million & 34 & $12.4 \%$ & 24.9 & $6.0 \%$ \\
\hline$\$ 2-\$ 4$ million & 54 & $13.5 \%$ & 22.9 & $7.1 \%$ \\
\hline$\$ 4-\$ 7$ million & 63 & $10.6 \%$ & 26.0 & $4.9 \%$ \\
\hline$\$ 7-\$ 10$ million & 35 & $22.1 \%$ & 30.3 & $4.8 \%$ \\
\hline$\$ 10-\$ 15$ million & 38 & $12.7 \%$ & 31.7 & $8.0 \%$ \\
\hline$\$ 15-\$ 25$ million & 27 & $21.3 \%$ & 32.0 & $6.9 \%$ \\
\hline$>\$ 25$ million & 18 & $15.4 \%$ & 26.7 & $6.2 \%$ \\
\hline Total & 269 & $14.2 \%$ & 27.3 & \\
\hline Foreclosure Year & & & & $6.4 \%$ \\
\hline $1986-90$ & 117 & $20.4 \%$ & 38.4 & $6.1 \%$ \\
\hline $1991-95$ & 152 & $9.5 \%$ & 18.7 & 27.3 \\
\hline Total & 269 & $14.2 \%$ & & \\
\hline
\end{tabular}


Table 8

Firesale Discount Estimates on Foreclosed Asset Sales

Table 8 reports various estimates of the firesale discount associated with foreclosed assets that are sold during the sample period. Panel A organizes the data by year of foreclosure and Panel B organizes the data by year of asset sale. Loan balance in column (2) is as of the time of foreclosure. CapX in columns (4) and (5) is the present value of capital expenditure incurred over the asset holding period, discounted to the foreclosure date at a 10 percent rate. For the one observation with missing capx, we use the annual sample average together with actual holding period data. The adjusted asset sale price in column (5) is the asset sale price adjusted for changes in the NCREIF property index that were realized over the asset holding period. This adjustment controls for holding period market price change effects.

\section{Panel A: Asset Sales By Year of Foreclosure}

\begin{tabular}{|c|c|c|c|c|c|c|}
\hline $\begin{array}{l}\text { Fore- } \\
\text { closure } \\
\text { Year }\end{array}$ & $\begin{array}{l}\text { Number of } \\
\text { Sold Assets } \\
\text { (1) }\end{array}$ & $\begin{array}{c}\text { Transfer Value / } \\
\text { Loan Balance } \\
\text { (2) }\end{array}$ & $\begin{array}{c}\text { Asset Sale Price / } \\
\text { Transfer Value } \\
\text { (3) }\end{array}$ & $\begin{array}{l}\text { Asset Sale Price / } \\
\text { (TV + CapX) } \\
\text { (4) }\end{array}$ & $\begin{array}{c}\text { Adjusted Asset } \\
\text { Sale Price / } \\
\text { (TV + CapX) } \\
\text { (5) }\end{array}$ & $\begin{array}{c}\text { Time to } \\
\text { Asset Sale } \\
\text { (Months) } \\
\text { (6) }\end{array}$ \\
\hline 1986 & 16 & .905 & .690 & .611 & .661 & 53.9 \\
\hline 1987 & 24 & .983 & .688 & .631 & .672 & 40.4 \\
\hline 1988 & 24 & .766 & .757 & .691 & .799 & 39.9 \\
\hline 1989 & 29 & .747 & .751 & .674 & .821 & 40.3 \\
\hline 1990 & 24 & .774 & .778 & .713 & .877 & 29.4 \\
\hline 1991 & 49 & .802 & .670 & .623 & .780 & 28.7 \\
\hline 1992 & 52 & .808 & .777 & .734 & .829 & 16.9 \\
\hline 1993 & 34 & .675 & .783 & .759 & .781 & 10.2 \\
\hline 1994 & 16 & .632 & .986 & .970 & .970 & 4.2 \\
\hline 1995 & 2 & .618 & 1.155 & 1.132 & 1.276 & 6.7 \\
\hline Total & 270 & .786 & .756 & .705 & .801 & 27.3 \\
\hline
\end{tabular}

Panel B: Asset Sales By Year of Asset Sale

\begin{tabular}{|c|c|c|c|c|c|c|}
\hline $\begin{array}{l}\text { Asset } \\
\text { Sale } \\
\text { Year }\end{array}$ & $\begin{array}{l}\text { Number of } \\
\text { Sold Assets } \\
\text { (1) }\end{array}$ & $\begin{array}{l}\text { Transfer Value / } \\
\text { Loan Balance } \\
\text { (2) }\end{array}$ & $\begin{array}{c}\text { Asset Sale Price / } \\
\text { Transfer Value } \\
\text { (3) }\end{array}$ & $\begin{array}{l}\text { Asset Sale Price / } \\
\text { (TV + CapX) } \\
\text { (4) }\end{array}$ & $\begin{array}{c}\text { Adjusted Asset } \\
\text { Sale Price / } \\
\text { (TV + CapX) } \\
\text { (5) }\end{array}$ & $\begin{array}{c}\text { Time to } \\
\text { Asset Sale } \\
\text { (6) }\end{array}$ \\
\hline 1987 & 2 & 1.068 & .928 & .903 & .913 & 7.9 \\
\hline 1988 & 4 & .848 & 1.223 & 1.136 & 1.142 & 17.1 \\
\hline 1989 & 27 & .916 & .808 & .747 & .751 & 27.3 \\
\hline 1990 & 17 & .776 & .700 & .652 & .663 & 30.3 \\
\hline 1991 & 19 & .789 & .886 & .825 & .887 & 21.3 \\
\hline 1992 & 24 & .754 & .798 & .750 & .867 & 19.6 \\
\hline 1993 & 79 & .824 & .739 & .689 & .830 & 31.3 \\
\hline 1994 & 85 & .738 & .706 & .657 & .773 & 27.4 \\
\hline 1995 & 13 & .609 & .720 & .707 & .802 & 26.5 \\
\hline Total & 270 & .786 & .756 & .705 & .801 & 27.3 \\
\hline & & & & & & \\
\hline
\end{tabular}


Table 9

A Test of Stage-3 Model Predictions: The Lender's Inventory Asset Sale Decision

Table 9 reports coefficient estimates from a proportional hazards model of the time to repossessed asset sale. The dependent variable takes on a value of 1 if the repossessed asset is sold during a particular quarter and zero if the repossessed asset remains in the lender's inventory. The sample includes only foreclosed assets that were actually sold by the end of the 1995. Sample size is 241 , as 29 observations were excluded due to missing values. Standard errors for the estimated coefficients are in parentheses. Asterisks indicate statistical significance based on the Wald Chi-Square measure: denotes significance at the $1 \%$ level, ${ }^{* *}$ denotes significance at the $5 \%$ level, and ${ }^{*}$ denotes significance at the $10 \%$ level. Several additional variables are included as controls in the specification. These variables are a Bankruptcy dummy variable, indicating if the loan was part of a larger bankruptcy proceeding; a Package Sale dummy variable, indicating if the asset sale was part of a bulk (multi-asset) sale transaction; and a Seller Financing dummy variable, indicating whether the lender provided purchase money financing as part of the asset sale transaction.

\begin{tabular}{|c|c|}
\hline $\begin{array}{c}\text { Independent Variable } \\
\text { (Model Variable Reference) }\end{array}$ & $\begin{array}{c}\text { Coefficient Estimate } \\
\text { (Standard Error) }\end{array}$ \\
\hline $\begin{array}{l}\text { Apartment } \\
(\mathrm{W})\end{array}$ & $\begin{array}{c}0.808^{* * *} \\
(.190)\end{array}$ \\
\hline $\begin{array}{l}\text { Hotel } \\
(\mathrm{W}, \beta)\end{array}$ & $\begin{array}{l}-0.114 \\
(.330)\end{array}$ \\
\hline $\begin{array}{l}\text { Industrial } \\
\text { (W) }\end{array}$ & $\begin{array}{l}0.397^{*} \\
(.231)\end{array}$ \\
\hline $\begin{array}{c}\text { Retail } \\
\text { (W) }\end{array}$ & $\begin{array}{l}0.170 \\
(.196)\end{array}$ \\
\hline $\begin{array}{l}\text { Other } \\
\text { (W) }\end{array}$ & $\begin{array}{l}0.675 \\
(.514)\end{array}$ \\
\hline $\begin{array}{c}\text { Transfer Value } \\
(\mathrm{W}, \beta)\end{array}$ & $\begin{array}{l}-0.010 \\
(.009)\end{array}$ \\
\hline $\begin{array}{l}\text { REIT Price } \\
\text { (W) }\end{array}$ & $\begin{array}{c}0.020^{* * *} \\
(.003)\end{array}$ \\
\hline $\begin{array}{l}\text { Bankruptcy } \\
\text { (Control) }\end{array}$ & $\begin{array}{l}0.649^{* * *} \\
(.242)\end{array}$ \\
\hline $\begin{array}{l}\text { Package Sale } \\
\text { (Control) }\end{array}$ & $\begin{array}{l}-0.257^{*} \\
(.139)\end{array}$ \\
\hline $\begin{array}{l}\text { Seller Financing } \\
\text { (Control) }\end{array}$ & $\begin{array}{l}-0.107 \\
(.225)\end{array}$ \\
\hline Model Chi-Square & $79.1^{* * 76}$ \\
\hline
\end{tabular}


Table 10

A Test of Stage-2 Model Predictions:

\section{The Lender's Restructuring Versus Foreclosure Decision}

Table 10 presents logit model coefficient estimates of the lender's decision whether to restructure (0) or foreclose (1) a defaulted commercial mortgage loan. There are a total of 289 restructured loans and 342 foreclosed loans in the sample. Standard errors for the estimated coefficients are in parentheses. Asterisks denote statistical significance based on the ChiSquare Score measure: ${ }^{* * *}$ denotes significance at the $1 \%$ level, ${ }^{* *}$ denotes significance at the $5 \%$ level, and ${ }^{*}$ denotes significance at the $10 \%$ level. Several additional variables are included as controls. These variables are: Loan-to-value ratio at loan origination; Debt service coverage ratio at loan origination, defined as net operating income divided by debt service; Loan term-to-maturity at origination; Loan age at the onset date of financial distress; Borrower type-individual, Borrower type-partnership, Borrower type-other; a dummy variable indicating if Judicial Sale (as opposed to Power-of-Sale) foreclosure law applies; a Second Mortgage dummy variable, indicating if the borrower had a secondary source of debt financing; and a Bankruptcy dummy variable, indicating if the loan was part of a larger bankruptcy proceeding.

\begin{tabular}{|c|c|}
\hline $\begin{array}{c}\text { Independent Variable } \\
\text { (Model Variable Reference) }\end{array}$ & $\begin{array}{l}\text { Coefficient Estimate } \\
\text { (Standard Error) }\end{array}$ \\
\hline Intercept & $\begin{array}{l}-1.31 \\
(2.02) \\
\end{array}$ \\
\hline $\begin{array}{l}\text { Apartment } \\
\text { (B) }\end{array}$ & $\begin{array}{l}-1.25^{* * * *} \\
(.238)\end{array}$ \\
\hline $\begin{array}{l}\text { Industrial } \\
\text { (B) }\end{array}$ & $\begin{array}{l}-0.202 \\
(.318)\end{array}$ \\
\hline $\begin{array}{l}\text { Retail } \\
\text { (B) }\end{array}$ & $\begin{array}{l}0.013 \\
(.304)\end{array}$ \\
\hline $\begin{array}{l}\text { Other } \\
\text { (B) }\end{array}$ & $\begin{array}{l}-0.115 \\
(.787) \\
\end{array}$ \\
\hline $\begin{array}{c}\text { REIT Price }(\mathrm{t}) \\
(\mathrm{W})\end{array}$ & $\begin{array}{l}0.009^{*} \\
(.005)\end{array}$ \\
\hline $\begin{array}{l}\text { Beginning Inventory }(\mathrm{t}) \\
(\mathrm{W}, \mathrm{K})\end{array}$ & $\begin{array}{c}-0.013^{* * *} \\
(.002)\end{array}$ \\
\hline $\begin{array}{l}\text { Hotel } \\
(\beta)\end{array}$ & $\begin{array}{c}-1.41^{* * * *} \\
(.482)\end{array}$ \\
\hline $\begin{array}{l}\text { Loan Size } \\
\quad(\beta)\end{array}$ & $\begin{array}{c}-0.022^{* * *} \\
(.007)\end{array}$ \\
\hline $\begin{array}{c}\text { Loan-to-Value Ratio } \\
\text { (Control) }\end{array}$ & $\begin{array}{c}0.015 \\
(.0200) \\
\end{array}$ \\
\hline $\begin{array}{l}\text { Debt Service Coverage Ratio } \\
\text { (Control) }\end{array}$ & $\begin{array}{c}0.954 \\
(0.716)\end{array}$ \\
\hline $\begin{array}{c}\text { Loan Term } \\
\text { (Control) }\end{array}$ & $\begin{array}{l}-0.003 \\
(.003)\end{array}$ \\
\hline $\begin{array}{l}\text { Loan Age } \\
\text { (Control) }\end{array}$ & $\begin{array}{l}0.029 \\
(.047)\end{array}$ \\
\hline $\begin{array}{c}\text { Borrower Type - Individual } \\
(\text { Control })\end{array}$ & $\begin{array}{l}-0.035 \\
(.430)\end{array}$ \\
\hline $\begin{array}{l}\text { Borrower Type - Partnership } \\
\text { (Control) }\end{array}$ & $\begin{array}{l}-0.156 \\
(.251)\end{array}$ \\
\hline $\begin{array}{c}\text { Borrower Type - Other } \\
\text { (Control) }\end{array}$ & $\begin{array}{l}-0.055 \\
(.367)\end{array}$ \\
\hline $\begin{array}{c}\text { Judicial Sale } \\
\text { (Control) }\end{array}$ & $\begin{array}{l}0.406^{* *} \\
(.203)\end{array}$ \\
\hline $\begin{array}{l}\text { Second Mortgage } \\
\text { (Control) }\end{array}$ & $\begin{array}{l}-0.394^{*} \\
(.220)\end{array}$ \\
\hline $\begin{array}{c}\text { Bankruptcy } \\
\text { (Control) }\end{array}$ & $\begin{array}{l}0.317 \\
(.375) \\
\end{array}$ \\
\hline Model Chi-Square & $117.9^{* * *}$ \\
\hline
\end{tabular}

